MICHIGAN RETIREMENT AND DISABILITY RESEARCH CENTER UNIVERSITY OF MICHIGAN

Promoting research on retirement, disability, and Social Security policy

\title{
Cognitive Ability, Cognitive Aging, and Debt Accumulation
}

Marco Angrisani, Jeremy Burke, and Arie Kapteyn

MRDRC WP 2020-411

UM20-11 


\section{Cognitive Ability, Cognitive Aging, and Debt Accumulation}

\author{
Marco Angrisani \\ University of Southern California
}

\author{
Jeremy Burke \\ University of Southern California
}

Arie Kapteyn
University of Southern California

September 2020

Michigan Retirement and Disability Research Center, University of Michigan, P.O. Box 1248. Ann Arbor, Ml 48104, mrdrc.isr.umich.edu, (734) 615-0422

\section{Acknowledgements}

The research reported herein was performed pursuant to a grant from the U.S. Social Security Administration (SSA) funded as part of the Retirement and Disability Research Consortium through the University of Michigan Retirement and Disability Research Center Award RDR18000002-02. The opinions and conclusions expressed are solely those of the author(s) and do not represent the opinions or policy of SSA or any agency of the federal government, the University of Michigan, or the University of Southern California. Neither the United States government nor any agency thereof, nor any of their employees, makes any warranty, express or implied, or assumes any legal liability or responsibility for the accuracy, completeness, or usefulness of the contents of this report. Reference herein to any specific commercial product, process or service by trade name, trademark, manufacturer, or otherwise does not necessarily constitute or imply endorsement, recommendation or favoring by the United States government or any agency thereof.

\section{Regents of the University of Michigan}

Jordan B. Acker; Huntington Woods; Michael J. Behm, Grand Blanc; Mark J. Bernstein, Ann Arbor; Paul W. Brown, Ann Arbor; Shauna Ryder Diggs, Grosse Pointe; Denise llitch, Bingham Farms; Ron Weiser, Ann Arbor; Katherine E. White, Ann Arbor; Mark S. Schlissel, ex officio 


\title{
Cognitive Ability, Cognitive Aging, and Debt Accumulation
}

\begin{abstract}
In the past few decades, financial products targeting consumers have become increasingly complex, and recent evidence suggests that older adults are entering retirement with more debt than previous generations. We examine how cognitive ability relates to debt burdens among older adults and whether this relationship has changed over time with the increasingly complex financial landscape. Using data from the Health and Retirement Study spanning 1998 to 2014, we find that cognitive ability is an important predictor of debt burdens in older age and that, in more complex financial environments, individuals with higher cognitive ability have taken on higher debt levels than individuals with lower cognitive ability. In a complementary analysis using data from 2015 to 2019 drawn from the Understanding America Study, we find similar results and evidence that the relationship between cognitive ability and debt exposure is driven by financial sophistication. Our findings are broadly inconsistent with the scenario of financial intermediaries pushing increasingly complicated financial products onto unsophisticated borrowers. However, we find that even higher cognitive ability individuals may have difficulty managing their debt burdens in more complex environments: They hold less total wealth, less liquid wealth, and are more likely to have debt levels that exceed half their assets than their counterparts prior to the expansion in complexity. All told, we find that individuals with higher cognitive ability disproportionately increased their debt burdens during the increase in financial product complexity, and that subsequently, they were more financially fragile than similar individuals in previous cohorts.
\end{abstract}

\section{Citation}

Angrisani, Marco, Jeremy Burke, and Arie Kapteyn. 2020. "Cognitive Ability, Cognitive Aging, and Debt Accumulation." Ann Arbor, MI. University of Michigan Retirement and Disability Research Center (MRDRC) Working Paper; MRDRC WP 2020-411.

https://mrdrc.isr.umich.edu/publications/papers/pdf/wp411.pdf 


\section{Introduction}

While a large literature has examined savings behavior and accumulation among older adults, relatively little research has explored older adults' debt behaviors and outcomes. Recent work by Lusardi, Mitchell, and Oggero (2020) documents that older adults from recent generations tend to hold more debt than their predecessors, particularly mortgage debt. Holding large debt loads near retirement age may increase financial insecurity - borrowers may be adversely impacted by rising interest rates and at higher likelihood of declaring bankruptcy. Additionally, highly indebted seniors may have to devote a larger fraction of their retirement income to service their debts, leaving them particularly vulnerable to income or asset shocks, as well as to unexpected, large medical expenses.

While documenting increasing debt exposure among older adults is a crucial first step, developing policy interventions to counteract it requires identifying the underlying drivers of the observed surge in debt burdens. Previous work has identified several possible contributing factors that may have led to increased debt burdens in the population at large. First, prior research has argued that rising house prices and easier access to credit have played an important role (Dynan and Kohn 2007; Mian and Sufi 2011). Other research has noted that adoption of risk-based pricing both lowered costs for low-risk borrowers and expanded access to credit for high-risk borrowers, leading to increased borrowing, particularly for lower-risk households (Edelberg 2006).

Another possibility is the surge in financial product complexity observed in the past two decades. As noted by Amromin et al. (2018), complex mortgages with zero or negative amortization, such as interest-only and negative-amortization mortgages, 
surged in the early 2000 s and subsequently contracted sharply after the 2007 to 2009 financial crisis. Figure 1 depicts the yearly composition of originated mortgages types between 1998 and 2009. It shows that interest-only and negative-amortization loans were basically nonexistent in 1998 , yet rose to about $30 \%$ of mortgage originations in 2006. Célérier and Vallee (2017) document that other financial instruments targeted at households (particularly retail structured products) also increased in complexity during the early-to-mid 2000 s.

As a result of a substantial increase in the financial landscape's complexity, consumers from later cohorts may have difficulty appropriately selecting among and using these increasingly complicated instruments (Brown et al. 2017; Hastings and Mitchell 2018). This difficulty may be compounded by misleading sales tactics obscuring or shrouding important borrowing terms (Gabaix and Laibson 2006; Gurun, Matvos, and Seru 2016; Agarwal et al. 2016).

While considerable progress has been made in understanding the consumer-debt explosion, less work has examined the drivers in increased debt burdens at older ages. Increasing product complexity may be a particularly important driver for debt accumulation among older individuals, who may have more difficulty managing their debt burdens and selecting appropriate financial contracts. Agarwal et al. (2009) document that financial sophistication follows an inverse U-shaped pattern, peaking in middle age and then declining. Difficulty navigating the increasingly complex financial landscape may be particularly acute for individuals with low cognitive ability and older individuals experiencing cognitive decline. As the financial landscape has become progressively more complex, the rise in debt burdens may be concentrated on those 
who are less cognitively able, raising concerns about the economic security of individuals who may not be adequately equipped to navigate the system.

In this paper, we use data from the Health and Retirement Study (HRS) to examine how cognitive ability and cognitive aging relate to debt accumulation among older adults, and how this varies over time as financial products have become progressively more complex. In similar spirit to, and building upon, Lusardi, Mitchell, and Oggero (2020), we create three age groups, 56 to 61 (preretirement age), 62 to 67 (retirement age), and 68 to 73 (post-retirement age), each observed at three different points in time, namely 1998, 2006, and 2014, and therefore, belonging to different cohorts (e.g., those 56 to 61 surveyed in 1998 were born 1937 to 1942, those 56 to 61 surveyed in 2006 were born 1945 to 1950 , those 56 to 61 surveyed in 2014 were born 1953 to 1958). The difference between time periods allows us to compare cohorts relatively unexposed to a surge in financial product complexity (1998), those exposed to increasing complexity yet observed prior to the financial crisis (2006), and those who faced increasing complexity and observed after the crisis (2014).

Similar to prior research, we find that debt burdens among those approaching retirement age have increased substantially in the past two decades. We also show that this pattern extends to individuals who are post-retirement age (ages 68 to 73 ). The fraction of individuals holding debt in this age group increased from $37 \%$ in 1998 to $54 \%$ in 2014 , and average debt burdens more than doubled.

Of central interest to this paper, we find that cognitive ability is an important predictor of debt burdens in older age, and that this relationship has changed over time. In particular, those with higher cognitive ability have taken on higher debt levels relative to 
their lower cognitive ability counterparts in more complex financial environments. This pattern holds across age groups, and is particularly pronounced post-crisis. Much of the total debt increase is due to higher cognitive ability individuals taking on more mortgage debt. We also find evidence that older adults with higher cognitive ability take on more mortgage debt in response to increasing local home prices than their lower cognitive ability counterparts. However, these patterns are not confined solely to housing debt: Older adults with higher cognitive ability take on more "other debt," which includes credit card debt, in more complex financial environments.

We complement this analysis with additional data drawn from the Understanding America Study (UAS). The UAS data span the 2015 to 2019 time period and allow us to verify the robustness of the relationship between cognitive ability and debt burdens in more recent years. Furthermore, our UAS data contain a wealth of additional characteristics, including financial literacy, enabling us to examine the extent to which the relationship between cognitive ability and debt exposure is driven by financial sophistication. After controlling for financial literacy, the relationship between debt burdens and cognitive ability essentially vanishes, highlighting the fact that it is the more financially sophisticated who appear to be taking on more debt in increasingly complex financial environments.

Broadly, our findings are inconsistent with a story that financial intermediaries are pushing increasingly complex financial products onto unsophisticated borrowers. Rather, our evidence is in line with recent research suggesting that risky and complex financial instruments are more likely to be adopted by relatively financially sophisticated individuals (van Ooijen and van Rooij 2016; Amromin et al. 2018). However, we find 
evidence that even higher cognitive ability individuals may have difficulty managing their debt burdens in more complex environments. After the increase in financial complexity, and particularly after the financial crisis, individuals with higher cognitive ability hold less total wealth, less liquid wealth, and are more likely to have debt levels that exceed half their assets than their higher cognitive ability counterparts prior to the expansion in complexity. All told, we find that higher cognitive ability individuals disproportionately increased their debt burdens during the increase in financial product complexity, and that subsequently, they were more financially fragile than similar individuals in previous cohorts.

The remainder of the paper proceeds as follows. Section 2 briefly describes the data used for this study. Section 3 documents results from our analyses using HRS data, while Section 4 presents results using UAS data. Section 5 concludes. All figures and tables have been relegated to the Appendix.

\section{Data}

We draw data from multiple sources. First, we leverage multiple waves of the Health and Retirement Study (HRS). The HRS is a longitudinal panel study that surveys a representative sample of approximately 20,000 Americans 50 and older every two years. The HRS contains a wealth of information on its participants, including demographic, financial, and health characteristics. Importantly for our analyses, the HRS comprehensively measures both cognitive ability and debt burdens. Total debt, as elicited by the HRS, sums four components: first and second mortgages on one's primary residence, other home loans, mortgage debt on a second home, and other debt (including credit card debt, medical debt, and other loans). Since 1995, the HRS has 
used a 27-point scale of working and episodic memory to measure cognition for all respondents (Crimmins et al. 2011). A composite index of cognitive ability is obtained by summing scores on immediate and delayed word recall ( 0 to 20 points) test, a serial $7 \mathrm{~s}$ test, which asks respondents subtract seven from 100 and then continue to subtract seven from the resulting figure five times ( 0 to 5 points), and a backward counting test from 20 (0 to 2 points). The tests derive from the Mini-Mental State Examination and display suitable psychometric properties (Herzog and Rodgers 1999).

In addition to the HRS public use files, we rely on individual-level, restricted geographic information (HRS Cross Wave Geographic data file) to merge in local house prices as measured by the Zillow Home Value Index (ZHVI). To construct the index, Zillow estimates the value of each house within a zip code based on property characteristics, recent local sales, then takes the median estimated price for each zip code and applies a five-month moving average and seasonal adjustments to create the ZHVI. Our ZHVI data date back to April 1996 and are available for more than threequarters of our observations. For our analyses, we create one-year (percentage) change measures in the $\mathrm{ZHVI}$ for each respondent based upon their beginning interview date.

We complement the analysis based on HRS data with further analysis using data from the Understanding America Study (UAS), an online panel of about 9,000 members representative of the adult U.S. population. The entire HRS questionnaire is administered to all UAS panel members every two years. Several "core" UAS surveys elicit additional information about respondents on a biennial basis. This includes cognitive ability level and financial literacy, personality traits, subjective well-being, 
retirement, and knowledge of Social Security rules, among others. Data from HRS modules and core surveys are merged together into one, user-friendly data set, the UAS Comprehensive File (CF). ${ }^{1}$ This data set also provides imputation and harmonization of HRS variables following a similar methodology, structure, and naming conventions to that of the RAND-HRS File Data, from where we obtain the HRS data described above.

We construct a dataset drawing from three HRS waves - 1998, 2006, and 2014 covering a period prior to the onset of rapidly increasing financial complexity (particularly mortgage complexity), a period after the increase in complexity and prior to the 2007 to 2008 Great Recession, and a period post-increase in complexity and postcrisis, respectively. Within each year, we create three age groups, 56 to 61 (preretirement age), 62 to 67 (retirement age), and 68 to 73 (post-retirement age). Across years these age groups belong to three different cohorts, e.g., those 56 to 61 surveyed in 1998 were born 1937 to 1942, those 56 to 61 surveyed in 2006 were born 1945 to 1950, those 56 to 61 surveyed in 2014 were born 1953 to 1958.

We use the UAS CF as of June 2020. To mimic the HRS data analysis, we select individuals between the ages of 56 and 73 . After excluding respondents with missing values on relevant variables, we are left with 2,825 observations, spanning the years 2015 to 2019 , and 1,683 unique individuals (about $68 \%$ of sampled individuals are observed twice). We have at our disposal exactly the same variables for debt exposure and wealth components as in the HRS. Moreover, we observe subjective perceptions of debt load, which we use to complement the analysis using "objective" measures of debt

${ }^{1}$ The UAS Comprehensive File and related documentation can be found at https://uasdata.usc.edu/index.php\#. 
level. The UAS measures cognitive ability through a comprehensive battery of tests 15 tests for numeracy, 15 tests for picture vocabulary, and 15 tests for verbal analogies. We sum the scores across these 45 cognitive tests to form a total cognitive ability index score, which we then transform to take mean zero and standard deviation one in the sample. Unlike the HRS, the UAS elicits individuals' level of financial literacy using 14 questions covering topics from compound interest rate and inflation to risk and return of different assets and house prices. We create a composite score for financial literacy by summing the number of correct answers across these questions. As for cognitive ability, we standardize this index within the sample.

\section{Evidence from the Health and Retirement Study}

\subsection{Debt burden increases across cohorts}

Using HRS data, Table 1 documents how debt levels compare across the three cohorts and across years. Relative to 1998 and across our age groups, total debt burdens (in 2014 dollars) increased substantially following the increase in financial product complexity. For example, $64 \%$ of respondents ages 56 to 61 carried at least some debt in 1998 , while this figure rose to $73 \%$ in 2006 and $69 \%$ in 2014 . Not only did more people hold debt, but, on average, they held more of it. The mean debt burden among those ages 56 to 61 was more than $\$ 60,000$ in 1998 , but increased by approximately $50 \%$ in 2006 and 2014 to $\$ 92,000$ and $\$ 89,000$, respectively.

The rise in debt was particularly large, and perhaps particularly troubling, for the oldest age group. In 1998, only $37 \%$ of respondents ages 68 to 73 had debt, yet this figure rose to $46 \%$ in 2006 , and $54 \%$ in 2014 . Debt burdens also increased substantially 
for this age group, as mean debt levels rose from $\$ 22,000$ in 1998 to $\$ 39,000$ in 2006 and $\$ 47,000$ in 2014.

As in prior research, we find that a large portion of the increase in total debt across cohorts is driven by mortgage debt increases. Among respondents ages 56 to 61 , the fraction who held mortgage debt remained relatively stable across years, increasing from $43 \%$ in 1998 , to $51 \%$ and $45 \%$ in 2006 and 2014, respectively. Average debt burdens, however, increased markedly for this age group from $\$ 43,000$ in 1998 , to $\$ 70,000$ and $\$ 64,000$ in 2006 and 2014 . The increase in mortgage debt burden was even starker for the oldest age group. Approximately $20 \%$ of individuals ages 68 to 73 held mortgage debt in 1998 , yet this increased to $29 \%$ by 2014 . Simultaneously, average mortgage debt burdens nearly tripled from $\$ 16,000$ in 1998 to $\$ 35,000$ in 2014 .

While increasing mortgage debt on one's primary residence accounts for much of the total debt increase, it does not tell the entire story. Though held by fewer households, other home loan debt (such as home equity loans) and mortgage debt on secondary residences also increased for later cohorts, perhaps most notably for the oldest age group. About $5 \%$ of individuals ages 68 to 73 had other home loans against their primary residence in 1998, a figure doubling to $10 \%$ in 2006 and 2014 . Average balances also increased substantially, from approximately $\$ 1,600$ in 1998 to $\$ 6,100$ in 2006 and $\$ 4,300$ in 2014.

Perhaps of most concern, other debt, which includes unsecured debt, also rose across cohorts, particularly among the older age groups. Among respondents ages 68 to 73 , the incidence of other debt passed from $20 \%$ in 1998 to $34 \%$ in 2014 , while average debt burdens increased from $\$ 2,700$ to $\$ 4,200$. 


\subsection{Cognitive Ability's Evolving Influence on Debt Burdens}

As described above, our cognitive ability measure derives from a 27-point scale measuring working and episodic memory. Table 2 documents the difference in mean cognitive ability scores across cohorts and age groups. As expected, we see declines in cognitive ability across age groups within each year, with older adults having lower cognitive ability scores than their younger counterparts. Differences within age groups across years are muted, with no clear pattern over time.

To examine how cognitive ability is associated with debt burdens in older age, and how this varies across years and environments of different financial complexity, we estimate specifications of the following form:

$$
\text { (1) } \operatorname{Debt}_{i c}=\alpha+\beta \operatorname{Cog}_{i c}+\delta_{c}+\varphi\left(\operatorname{Cog}_{i c} * \delta_{c}\right)+X_{i c}{ }^{\prime} \gamma+\varepsilon_{i c}
$$

where $D e b t_{i c}$ is a debt outcome for individual $i$ from cohort $c,{ }^{2} \operatorname{Cog}_{i c}$ captures cognitive ability score, $\delta_{c}$ is a cohort fixed effect, and $X_{i c}$ is a vector of demographic, financial, and health characteristics. Our coefficient of interest, $\varphi$, captures differences in the relationship between cognitive ability and debt burdens across cohorts. We estimate Equation 1 for our entire sample and separately for each age group (e.g., when estimating it for the 56 to 61 group, we will have the 1937 to 1942 cohort surveyed in 1998, the 1945 to 1950 surveyed in 2006, and the 1953 to 1958 cohort surveyed in 2014) and compare the coefficients on the interaction of cognitive ability and cohort to assess whether those with higher cognition are accumulating disproportionately larger debt burdens in more financially complex environments.

${ }^{2}$ Given the skewed distribution of debt levels, we conducted a similar analysis after transforming debt using the inverse hyperbolic sine function. Results are similar, remain qualitatively unchanged, and are available from the authors upon request. 
We first estimate Equation 1 above omitting the interaction term to examine the relationship between cognitive ability and total debt burdens in our sample. Table 3 documents that, on average, individuals with higher cognitive ability carry more debt. In the full sample (Column 1), a one point increase in our cognitive ability score is associated $\$ 1,500$ increase in debt level. As might be expected, this relationship is larger among our preretirement age group, but persists even amongst the postretirement age group: Among adults age 68 to 73, a one point increase in the cognitive ability scale is associated with a $\$ 1,000$ increase in total debt. Consistent with the descriptive pattern documented in Table 1, the coefficients on our cohort indicators are large and highly significant. On average, older adults from later cohorts hold approximately $\$ 20,000$ more in debt than those observed prior to the increase in financial complexity. Men, married individuals, those with more children, white, higher educated, and individuals in fair or good health also tend to hold more debt than their counterparts.

Table 4 examines whether the relationship between cognitive ability and total debt burdens for older adults has changed during the period of increasing financial complexity. We find evidence that older adults with higher cognitive ability have taken on higher debt levels relative to their lower cognitive ability counterparts in more complex financial environments. For each additional point of the cognitive ability index, older adults held $\$ 1,100$ additional dollars in total debt in 2006 and $\$ 1,800$ additional dollars in total debt in 2014 relative to 1998. This pattern holds across age groups even for adults ages 68 to 73 . 
Table 5 shows that much of this increase in total debt is driven by rising mortgage debt on one's primary residence. Relative to 1998, a one-point increase in cognitive ability is associated with a $\$ 760$ increase in mortgage debt in 2006 , and a $\$ 1,400$ increase in mortgage debt in 2014. Higher cognitive ability is associated with taking on more debt in the prefinancial crisis period among individuals before retirement age. For them, a one-point increase in the cognitive ability score leads to an increase in mortgage debt that is twice as large in 2006 as in 1998 and 2014. For older adults (62 to 67 and 68 to 73 ), a better cognitive score correlates with more mortgage debt in the post-crisis period. Specifically, each additional point on the cognitive ability index is associated with $\$ 1,800$ and $\$ 1,400$ more in mortgage debt in 2014 relative to 1998 among 62 to 67 and 68 to 73 year-olds, respectively.

In addition to increasing financial complexity, there were dramatic shifts in housing prices and markets during the 1998 to 2014 period, with prices generally increasing substantially precrisis and falling precipitously after 2007. Importantly, there was also considerable variation in home price appreciation (and depreciation) across the country during our window of analysis, and prior research has documented sizeable responses of older households' expenditure (Angrisani, Hurd, and Rohwedder 2019), following heavy equity extraction during the boom and the drying up of this source of credit after the bust (Adelino et al. 2016). To examine the dynamics between cognitive ability, changes in house values, and increasing financial complexity, we construct a one-year change measure in home values at a respondent's zip-code level and augment our primary specification with this measure. Specifically, we add a triple interaction of 
cognitive ability, change in home prices, and cohort to our primary specification, alongside all the double interactions amongst these variables.

Table 6 presents the results. As anticipated, we find that rising local housing prices are associated with increased mortgage debt (Column 1). On average, each percentage point increase in change in yearly home prices is associated with $\$ 420$ in additional mortgage debt. Column 2 introduces the cognitive ability/home value price change interaction and shows that older adults with higher cognitive ability are more responsive to changing home prices. In particular, one additional point on the cognitive ability score is associated with a $\$ 300$ increase in mortgage debt for a $10 \%$ increase in house prices. Column 3 examines whether this relationship differs in periods with higher financial complexity. Though the point estimate on the year 2014 indicator is positive, we find little evidence of substantial differences in the cognitive ability/home price changes relationship pre- and post-increase in financial complexity.

While the previous analyses have documented that older adults with higher cognitive ability have accumulated higher debt levels during periods of increased financial complexity, driven in large part by mortgage debt, this pattern is not confined solely to mortgages. Table 7 shows that those with higher cognitive ability also borrowed more against their primary residence in other home loans, and that this relationship is stronger precrisis. In particular, a one-point increase in cognitive ability score is associated with $\$ 180$ increase in other home loan debt in 2006 and $\$ 130$ more home loan debt in 2014 relative to the period prior to the stark financial complexity increase. This pattern is driven primarily by the pre-retirement and post-retirement age groups. 
For both these age groups, the association is in excess of $\$ 200$ in 2006 and $\$ 170$ in 2014, relative to 1998 .

We also find evidence that the relationship between cognitive ability and debt levels over time extends beyond housing debt. In particular, older adults with higher cognitive ability take on more "other debt," which includes credit card debt, in more complex financial environments. Table 8 documents that this relationship holds, particularly postcrisis. On average, a one-point increase in cognitive ability is associated with a $\$ 50$ increase in other debt in 2006 (marginally significant) and a \$130 increase in other debt in 2014 , relative to 1998 . Similar to other home loans, the pattern observed in the overall sample is driven by the youngest and oldest age groups. Among adults ages 56 to 61 , each additional point in cognitive ability is associated with $\$ 160$ more other debt in 2006 and $\$ 180$ more in other debt in 2014.

\subsection{Cognitive ability and Financial Fragility}

The previous section documents that as the financial landscape became increasingly complex, relatively sophisticated individuals with higher cognitive ability became more indebted. This pattern is generally inconsistent with the story that financial intermediaries were systematically pushing increasingly complex financial instruments onto less sophisticated borrowers. Moreover, holding a high level of debt, particularly secured debt, is not unambiguously welfare reducing if households can manage the debt burdens effectively. However, we find evidence that older adults with higher cognitive ability have increased financial insecurity in more complex financial environments, consistent with the possibility that they are having difficulty managing their increased debt loads. 
Using Equation 1, Table 9 documents how the relationship between cognitive ability and net total wealth has evolved as the financial landscape has become more complex. ${ }^{3}$ Prior to the crisis, those with higher cognitive ability had higher wealth levels than their counterparts prior to the expansion in financial complexity. In particular, one additional point in the cognitive ability index is associated with $\$ 5,600$ more in wealth, on average, for individuals in 2006 relative to 1998. However, this relationship flips sign post-crisis: In 2014 , a one-point increase in cognitive ability is associated with $\$ 5,400$ less total wealth than prior to the increase in financial complexity. The association is particularly acute for the preretirement and the retirement age groups — for individuals ages 56 to 61 and 62 to 67 , a one-point increase in cognitive ability is associated with $\$ 8,700$ and $\$ 7,800$ less wealth in 2014 relative to 1998 , respectively.

Table 10 documents that individuals with higher cognitive ability post-crisis are more likely to hold debt burdens that are more than half their assets relative to their counterparts prior to the increase in financial complexity. In particular, a one-point increase in the cognitive ability index is associated with a half a percentage point increase in being highly leveraged, a $4 \%$ increase relative to the mean. This association is driven by the youngest and oldest age groups, with similar magnitudes to the observed relationship in the population at large.

Perhaps of most concern, much of the reduction in wealth for higher cognitive ability older adults post-crisis came in the form of lower liquid wealth (wealth in checking and

\footnotetext{
${ }^{3}$ Net total wealth is measured as the value of housing, other real estate, vehicles, businesses, IRAs, and liquid wealth net of debt. Similar to our analysis of debt above, we also examined specifications in which wealth levels are transformed using the inverse hyperbolic sine function to account for skewness. Results for liquid wealth remains qualitatively unchanged, though estimates for total wealth are no longer significant.
} 
savings, certificates of deposit, and bonds and stock outside of retirement accounts). ${ }^{4}$ Relative to the period prior to the financial complexity expansion, in 2014 a one-point increase in cognitive ability is associated with $\$ 3,800$ less in liquid wealth (Table 11). Troublingly, this relationship is particularly acute for adults age 68 to 73 , for whom a one-unit increase in cognitive ability is associated with $\$ 6,000$ less in liquid wealth. For this age group, the relationship is also evident precrisis. In 2006, an additional point in cognitive ability is associated with $\$ 2,800$ less liquid wealth than in 1998 (marginally significant). Lower levels of liquid wealth may be particularly problematic for postretirement aged adults for whom it may be difficult to deal with unexpected financial shocks through additional work.

\section{Evidence from the Understanding America Study}

In this section, we extend our analysis using data from the UAS, which administers the entire HRS questionnaire every two years to all panel members. Given this, we have at our disposal the very same debt and wealth measures in the UAS as in the HRS, alongside a comprehensive assessment of panel members' cognitive ability. Hence, we can check the robustness of the association between cognitive ability and debt exposure detected in the HRS among older American adults. Unlike the HRS, the UAS offers a comprehensive measure of financial literacy. This allows us to examine the extent to which the relationship between cognitive ability and debt exposure described above is driven by financial sophistication, an interpretation implicitly adopted so far when commenting on the estimated relationship between household debt and cognition.

\footnotetext{
${ }^{4}$ Overall patterns remain similar when we exclude stock holdings from liquid wealth.
} 
Moreover, we can assess whether cognitive ability has an independent effect on debt management beyond that of financial knowledge.

Following the same approach as above, we select individuals between the ages of 56 and 73 and classify them into three groups: the preretirement aged group (56 to 61), the retirement-aged group (62-65) and the post-retirement aged group (68 to 73). As before, we investigate differences in the effect of cognitive ability and financial literacy across these groups. UAS data refer to the period 2015 to 2019 , a time well after the surge in financial product complexity and relatively far from the Great Recession. This prevents us from comparing the behavior of the same age groups in different financial landscape scenarios. Thus, the results of this section speak to the effect of cognitive ability and financial literacy on debt exposure and heterogeneity across age groups in the current financial landscape, featuring a wide menu of available financial products and where individuals have all witnessed a period of increased financial complexity.

We adopt a similar model as in Equation 1

$$
\text { (2) } Y_{i}=\alpha+\beta_{1} \operatorname{Cog}_{i}+\beta_{2} \text { FinLit }_{i}+X_{i}{ }^{\prime} \gamma+\varepsilon_{i}
$$

where $Y_{i}$ is an outcome of interest (e.g., a measure of debt exposure, wealth, or financial fragility), $\operatorname{Cog}_{i}$ and FinLit $_{i}$ are standardized cognitive ability and financial literacy scores, respectively. The vector $X_{i}$ includes controls for age, gender, marital status, race, education, household income, poor health, working status, as well as year fixed effects. We first estimate Equation 2 with cognitive ability only and then add 
financial literacy to the specification. ${ }^{5}$ The results for debt exposure are reported in Table 11a, while those for wealth and financial fragility are shown in Table 12a.

As for the HRS data analysis, we find that cognitive ability is positively associated with total debt level, an effect primarily driven by primary-residence mortgage, and with total and liquid wealth. One advantage of using UAS data is the availability of subjective assessments of debt exposure and management. In particular, UAS members are asked to state whether they have no debt, a manageable amount of debt, a bit more debt than is manageable, or far more debt than is manageable. We construct an indicator for having "too much debt" if an individual reports having a bit more debt than is manageable or far more debt than is manageable. We also construct another indicator for a "biased perception" of debt, taking the value 1 if the observed debt-toasset ratio is greater than 2 , but the individual does not report having "too much debt." Finally, for debt holders, the UAS asks when they expect to repay their non-mortgage debt load. We create an indicator taking the value 1 if the respondent expects his/her debt load to be repaid in more than five years.

While we find positive associations between cognitive ability and debt level in both the HRS and UAS, we find a negative correlation between cognitive ability and subjective perceptions of debt load. A 1-standard deviation increase on the cognitive ability index decreases the probability of reporting having "too much debt" by 2 percentage points. Among debt holders, those with a higher cognitive ability score are less likely to state that it will take them more than five years to repay their debts. This underscores that while individuals with higher cognitive ability may be carrying higher

\footnotetext{
${ }^{5}$ We estimate a third specification, adding an interaction term between cognitive ability and financial literacy, and find no evidence of an interaction effect on debt exposure.
} 
debt burdens and are more financially fragile than similar individuals in the past, higher cognitive ability is still positively associated with financial well-being.

Interestingly, the correlation between cognitive ability and each outcome considered in the study vanishes when we add financial literacy to the regression. In contrast, we find a strong and significant association between financial literacy and all outcome variables, with the only exception of "other debt." Specifically, conditional on demographics and cognitive ability, a 1-standard deviation increase on the financial literacy score is associated with about $\$ 11,000$ more in total debt, $\$ 8,500$ more in mortgage on primary residence, $\$ 700$ more in other home loans, $\$ 120,000$ more in total wealth, and $\$ 29,000$ more in liquid wealth. Better financial literacy correlates negatively with the probability of having a debt-to-asset ratio greater than 2 , and with the subjective perceptions of debt load. In particular, a 1-standard deviation increase on the financial literacy score is associated with a nearly 4 percentage point decrease in the likelihood of reporting having too much debt, a 1.5 percentage point decrease in the likelihood of having a biased perception of debt exposure, and in a 4 percentage point decrease in the likelihood of expecting to repay debt in more than five years.

In view of these results, we explore heterogeneity in the effect of financial literacy across age groups by amending Equation 2 with age group indicators and their interaction with financial literacy. ${ }^{6}$ Tables $11 \mathrm{~b}$ and $12 \mathrm{~b}$ present the marginal effects of financial literacy separately evaluated for the preretirement age group (56 to 61), the retirement age group (62 to 67 ), and the post-retirement age group (68 to 73 ). As can

${ }^{6}$ Relative to the HRS, working with UAS data implies a significantly reduced sample size. We, therefore, prefer to explore heterogeneity by age group using interactions rather than separate regressions. Including interactions between age-group indicators and cognitive ability does not change the results reported in Tables $11 \mathrm{~b}$ and $12 \mathrm{~b}$. 
be seen in Table 11b, having a higher financial literacy score is associated with a substantially higher total debt level and primary home mortgage for individuals age 56 to 61 than for their older counterparts. For instance, a 1-standard deviation increase on the financial literacy score is associated with about $\$ 17,000$ more in total debt among 56 to 61 year olds, $\$ 5,600$ among 62 to 67 year-olds and $\$ 6,800$ among 68 to 73 year olds (with differences between the former and the two latter groups significant at $5 \%$ ). This finding is consistent with the effect of cognitive ability on total debt across age groups reported in Table 3.

As far as total and liquid wealth are concerned, we estimate a much stronger effect of financial literacy for the oldest group. A 1-standard deviation increase on the financial literacy score is associated with a $\$ 165,000 / \$ 5,500$ more in total/liquid wealth for those age 68 to 73 . These effects are significantly smaller in magnitude for younger individuals $-\$ 8,900 / \$ 2,600$ more in total/liquid wealth for those age 56 to 61 . These differences are still sizeable when we control for stock market participation, which is significantly higher among 68 to 73 year olds than among 56 to 61 year olds ( $26 \%$ versus $20 \%$, respectively). Specifically, conditional on stock market participation, a 1standard deviation increase on the financial literacy score is associated with a $\$ 121,000 / \$ 3,400$ more in total/liquid wealth for those age 68 to 73 and with a $\$ 5,000 / \$ 1,000$ more in total/liquid wealth for those age 68 to 73 . We observe very similar effects of financial literacy on the probability of reporting having too much debt across age groups, whereas the likelihood of having a biased perception of debt load is significantly lower for those with better financial knowledge among retirement-age individuals, but not within the other two groups. Finally, a 1-standard deviation increase 
on the financial literacy score is associated with a decrease in the likelihood of expecting to repay debt in more than five years of nearly 4 and 5 percentage points for those age 56 to 61 and 62 to 67 , respectively. In contrast, it has a much smaller impact among those age 68 to 73 , although differences among age groups are not statistically significant.

\section{Conclusion}

Existing research has documented that recent cohorts of older adults hold more debt than their predecessors and, as a result, may be more financially fragile. Yet little work has explored the underlying drivers of older adults' increasing indebtedness. In this paper, we examine how cognitive ability relates to older adults' debt burdens, and how this varies over time with the increasingly complex financial landscape.

Using data from the Health and Retirement Study and the Understanding America Study, we find that cognitive ability is an important predictor of debt burdens in older age, and that this relationship has changed over time during the period of expansion in financial complexity. Our results suggest that older adults with higher cognitive ability have taken on more debt relative to their counterparts in more complex financial environments. This relationship holds across our age groups of interest — adults 56 to 61 (preretirement age), 62 to 67 (retirement age), and 68 to 73 (post-retirement age) and is particularly pronounced post-financial crisis. Much of the increase in total debt is due to older adults with higher cognitive ability taking on disproportionately more mortgage debt. We find evidence that older adults with higher cognitive ability take on more mortgage debt in response to increasing local home prices than their counterparts with lower cognitive ability. Housing debt does not tell the entire story, however, as older 
adults with higher cognitive ability also took on more other debt (which includes credit card and medical debt) in the more complex financial environments.

While there has been some concern that greater financial complexity would disproportionately increase relatively unsophisticated consumers' indebtedness due to poor choice of debt instruments, this hypothesis does not seem well supported by the data. In fact, our results suggest that individuals with higher cognitive ability, and particularly higher financial literacy, are more likely to take on higher debt burdens in more complicated financial environments. This is consistent with research documenting that risky and complex financial instruments are more likely to be adopted by relatively financially sophisticated individuals (van Ooijen and van Rooij 2016; Amromin et al. 2018).

Though we do not find evidence that relatively financially naïve individuals are becoming disproportionately indebted in more complex financial landscapes, we do find evidence that higher cognitive ability individuals may be having difficulty managing their debt burdens in more complicated environments. After the increase in financial complexity, and particularly after the financial crisis, higher cognitive ability individuals hold less total wealth, less liquid wealth, and are more likely to have debt levels exceeding half their assets than their higher cognitive ability counterparts prior to the expansion in complexity. All told, we find that individuals with higher cognitive ability disproportionately increased their debt burdens during the increase in financial product complexity, and that subsequently, they were more financially fragile than similar individuals in previous cohorts. 
While our findings are in line with and build upon prior work, our analysis is unable to establish causality between increasing financial complexity and increasing debt burdens among individuals with high cognitive ability. However, our results do underscore the fact that recent cohorts of older adults are increasingly financially fragile and that this fragility is not confined solely to the less sophisticated. Older adults with larger debt burdens are, all else equal, more likely to be adversely impacted by financial shocks. Current and future retirees' financial security may be more in jeopardy across the financial sophistication spectrum, and older adults may be less financially resilient to financial shocks than past cohorts. An area of important future research is to examine how the COVID-19 crisis has affected older adults' retirement security and debt exposure. Our results suggest negative impacts may not be solely, or even primarily, confined to those who are less financially sophisticated. 


\section{References}

Adelino, Manuel, Antoinette Schoar, and Felipe Severino. 2016. "Loan Originations and Defaults in the Mortgage Crisis: The Role of the Middle Class." Review of Financial Studies, 29(7), 1635-70.

Agarwal, Sumit, Gene Amromin, Itzhak Ben-David, and Douglas Evanoff. 2016. "Loan Product Steering in Mortgage Markets." Working Paper 22696. Cambridge, MA: National Bureau of Economic Research.

Agarwal, Sumit, John C. Driscoll, Xavier Gabaix, and David Laibson. 2009. "The Age of Reason: Financial Decisions over the Life Cycle and Implications for Regulation." Brookings Papers on Economic Activity, Fall, 51-117.

Agarwal, Sumit, Gene Amromin, Itzhak Ben-David, and Douglas D. Evanoff. 2013. "Loan Product Steering in Mortgage Market." Working Paper

Amromin, Gene, Jennifer Huang, Clemens Sialm, and Edward Zhong. 2018. "Complex Mortgages" Review of Finance, 1975-2007

Angrisani, Marco, Michael Hurd, and Susann Rohwedder. 2019. "The Effect of Housing Wealth Losses on Spending in the Great Recession." Economic Inquiry, 57(2), 972-996

Brown, Jeffrey, Arie Kapteyn, Erzo Luttmer, and Olivia S. Mitchell. 2017. "Cognitive Constraints on Valuing Annuities," Journal of the European Economic Association, 15(2), 429-62

Célérier, Claire and Boris Vallée. 2017. "Catering to Investors through Security Design: Headline Rate and Complexity" Quarterly Journal of Economics 132(3), 14691508

Crimmins, Eileen M., Jung K. Kim, Kenneth M. Langa, and David R. Weir. 2011. "Assessment of Cognition Using Surveys and Neuropsychological Assessment: The Health and Retirement Study and the Aging, Demographics, and Memory 
Study," The Journals of Gerontology Series B: Psychological Sciences and Social Sciences, 66(1), i162-i171

Dynan, Karen E., and Donald L. Kohn. 2007. "The Rise in U.S. Household Indebtedness: Causes and Consequences." Finance and Economics Discussion Series Divisions of Research \& Statistics and Monetary Affairs. Federal Reserve Board Working Paper 37, 1-36.

Edelberg, Wendy. 2006. "Risk-Based Pricing of Interest Rates for Consumer Loans." Journal of Monetary Economics 53(8), 2283-2298.

Hastings, Justine and Olivia. S. Mitchell. 2018. "How Financial Literacy and Impatience Shape Retirement Wealth and Investment Behaviors," Pension Research Council Working Paper

Herzog, A. Regula and Willard L. Rodgers. 1999. "Cognitive Performance Measures in Survey Research on Older Adults." in Schwarz, N., Park, D., Knauper, B., Sudman, S. (Eds.), Cognition, Aging and Self-Reports. Psychology Press, Philadelphia. 327-340.

Gabaix, Xavier, and David Laibson. (2006). "Shrouded Attributes, Consumer Myopia, and Information Suppression in Competitive Markets." Quarterly Journal of Economics 121(2), 505-540.

Gurun, Umit, G., Gregor Matvos, and Amit Seru. (2016). "Advertising Expensive Mortgages." The Journal of Finance 71(5), 2371-2416.

Lusardi, Annamaria, Olivia S. Mitchell, and Noemi Oggero. 2020. Journal of Money, Credit and Banking 52(5): 1005-1034

Mian, Atif, and Amir Sufi. 2011. "House Prices, Home Equity-Based Borrowing, and the US Household Leverage Crisis." American Economic Review 101(5), 2132-2156.

van Ooijen, Raun and Maarten van Rooij. 2016. "Mortgage Risk, Debt Literacy, and Financial Advice." Journal of Banking and Finance 72(C), 201-217 
Figure 1: Increasing complexity in mortgage products

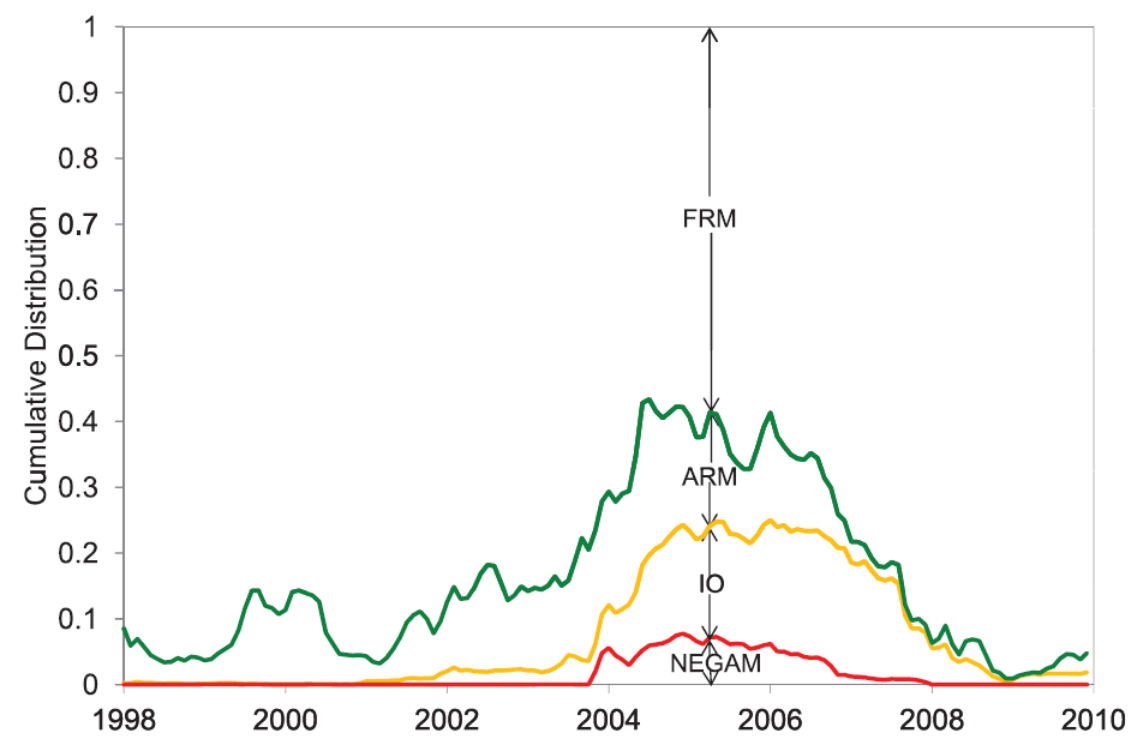

Source: Amromin et al. (2018). The figure shows the composition of fixed-rate mortgages (FRM), adjustable-rate mortgages (ARM), interest-only mortgages (IO), and negativeamortization mortgages (NEGAM) originated each year between 1998 and 2009. 
Table 1: Distribution of Debt Across Age Groups and Years

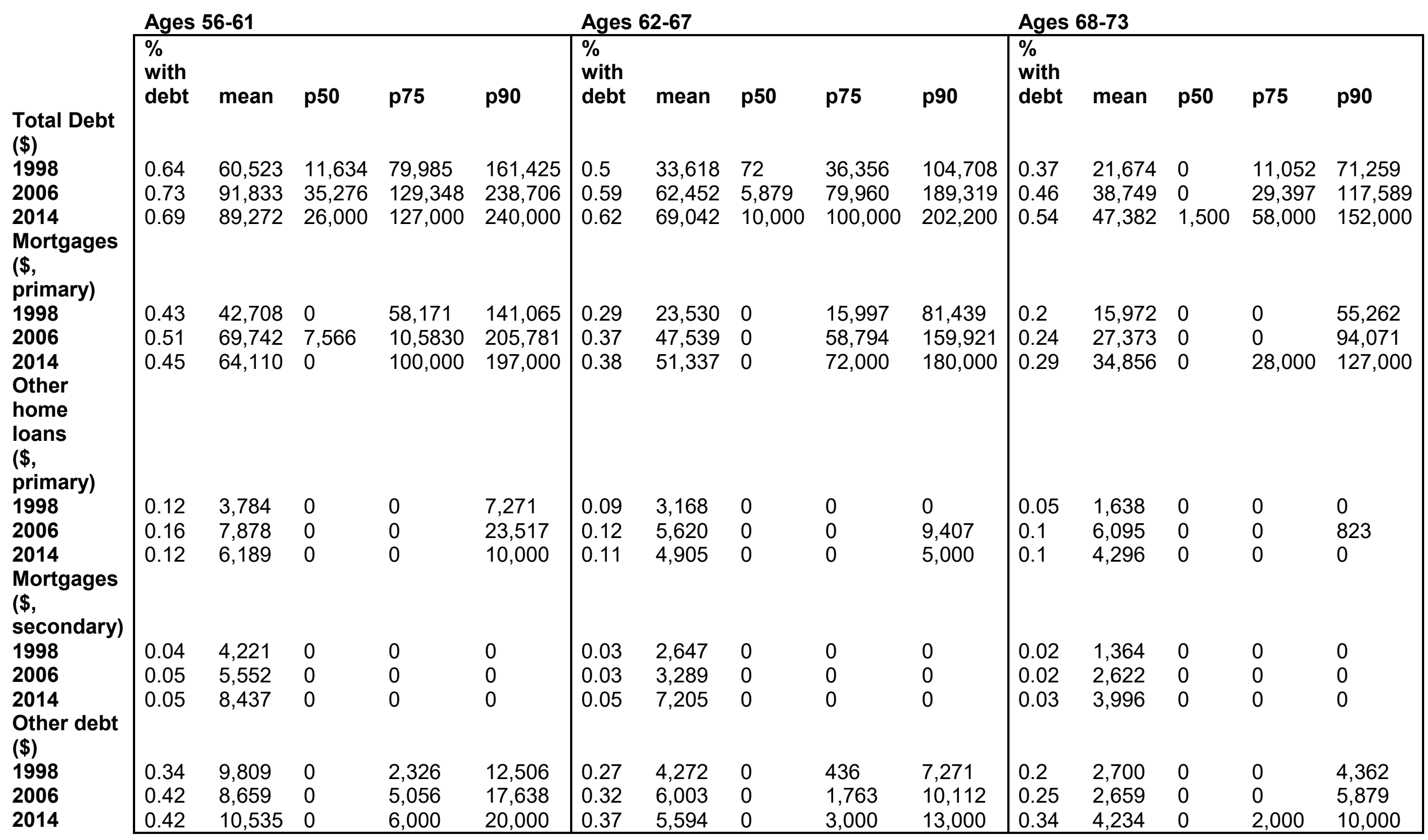

Notes: Total debt is the sum of primary and secondary mortgages on one's primary residence, other home loads on the primary residence, mortgages on secondary residences, and other debt, including credit card and medical debt. Data are weighted and indexed to 2014 dollars. 
Table 2: Average Cognitive Ability Score by Age Group and Year

\begin{tabular}{|l|c|c|c|}
\hline \multicolumn{4}{|c|}{ Age Group } \\
\hline & $\mathbf{5 6 - 6 1}$ & $\mathbf{6 2 - 6 7}$ & $\mathbf{6 8 - 7 3}$ \\
\hline \multirow{2}{*}{$\mathbf{1 9 9 8}$} & 17.39 & 16.64 & 15.04 \\
\cline { 2 - 4 } & {$[4.19]$} & {$[4.39]$} & {$[4.48]$} \\
\hline \multirow{2}{*}{2006} & 16.92 & 16.22 & 15.30 \\
\cline { 2 - 4 } & {$[4.16]$} & {$[4.22]$} & {$[4.27]$} \\
\hline \multirow{2}{*}{2014} & 16.78 & 16.7 & 15.68 \\
\cline { 2 - 4 } & {$[4.00]$} & {$[4.22]$} & {$[4.21]$} \\
\hline
\end{tabular}

Notes: The table depicts mean cognitive ability score across age groups and years. Standard deviations are in brackets. 
Table 3: Cognitive Ability and Total Debt by Age Group

\begin{tabular}{|c|c|c|c|c|}
\hline VARIABLES & $\begin{array}{l}1) \\
\text { Total Debt (\$10k) } \\
56-73\end{array}$ & $\begin{array}{l}(2) \\
\text { Total Debt }(\$ 10 k) \\
56-61\end{array}$ & $\begin{array}{l}(3) \\
\text { Total Debt (\$10k) } \\
62-67\end{array}$ & $\begin{array}{l}(4) \\
\text { Total Debt (\$10k) } \\
68-73\end{array}$ \\
\hline Cog Ability & $\begin{array}{l}0.150^{* * *} \\
(0.013)\end{array}$ & $\begin{array}{l}0.185^{* * *} \\
(0.021)\end{array}$ & $\begin{array}{l}0.148^{* * *} \\
(0.019)\end{array}$ & $\begin{array}{l}0.099 * * * \\
(0.017)\end{array}$ \\
\hline 2006 & $\begin{array}{l}1.927^{\star \star \star} \\
(0.103)\end{array}$ & $\begin{array}{l}2.548^{\star \star \star *} \\
(0.230)\end{array}$ & $\begin{array}{l}1.936^{\star \star *} \\
(0.185)\end{array}$ & $\begin{array}{l}1.044^{* * *} \\
(0.153)\end{array}$ \\
\hline 2014 & $\begin{array}{l}1.870^{* \star *} \\
(0.129)\end{array}$ & $\begin{array}{l}1.704^{* * *} \\
(0.207)\end{array}$ & $\begin{array}{l}1.953^{* * *} \\
(0.206)\end{array}$ & $\begin{array}{l}1.949^{* * *} \\
(0.198)\end{array}$ \\
\hline Age & $\begin{array}{l}-0.215^{* * *} \\
(0.009)\end{array}$ & $\begin{array}{l}-0.192^{* * *} \\
(0.051)\end{array}$ & $\begin{array}{l}-0.130^{* * *} \\
(0.047)\end{array}$ & $\begin{array}{l}-0.171^{* * *} \\
(0.042)\end{array}$ \\
\hline Female & $\begin{array}{l}-0.767^{\star \star \star} \\
(0.118)\end{array}$ & $\begin{array}{l}-0.848^{\star \star \star} \\
(0.180)\end{array}$ & $\begin{array}{l}-0.706^{\star \star \star} \\
(0.167)\end{array}$ & $\begin{array}{l}-0.820^{\star * *} \\
(0.156)\end{array}$ \\
\hline Married & $\begin{array}{l}1.947^{\star \star \star} \\
(0.129)\end{array}$ & $\begin{array}{l}2.879^{\star \star *} \\
(0.191)\end{array}$ & $\begin{array}{l}1.552^{\star \star \star} \\
(0.196)\end{array}$ & $\begin{array}{l}0.956^{\star \star \star} \\
(0.156)\end{array}$ \\
\hline Num children & $\begin{array}{l}0.097^{* * *} \\
(0.023)\end{array}$ & $\begin{array}{l}0.037 \\
(0.039)\end{array}$ & $\begin{array}{l}0.123^{* * *} \\
(0.035)\end{array}$ & $\begin{array}{l}0.155^{\star \star *} \\
(0.030)\end{array}$ \\
\hline White & $\begin{array}{l}0.431^{* * *} \\
(0.138)\end{array}$ & $\begin{array}{l}0.995^{\star * *} \\
(0.202)\end{array}$ & $\begin{array}{l}0.007 \\
(0.192)\end{array}$ & $\begin{array}{l}-0.426^{\star *} \\
(0.186)\end{array}$ \\
\hline More than HS & $\begin{array}{l}2.897^{* * *} \\
(0.144)\end{array}$ & $\begin{array}{l}3.668^{* * *} \\
(0.197)\end{array}$ & $\begin{array}{l}2.318^{* * *} \\
(0.190)\end{array}$ & $\begin{array}{l}2.198^{* * *} \\
(0.176)\end{array}$ \\
\hline HHI (\$10k) & $\begin{array}{l}0.040 \\
(0.025)\end{array}$ & $\begin{array}{l}0.026 \\
(0.022)\end{array}$ & $\begin{array}{l}0.123^{* * *} \\
(0.032)\end{array}$ & $\begin{array}{l}0.058^{* *} \\
(0.025)\end{array}$ \\
\hline Poor health & $\begin{array}{l}-0.692^{\star * *} \\
(0.109)\end{array}$ & $\begin{array}{l}-1.098^{\star * *} \\
(0.184)\end{array}$ & $\begin{array}{l}-0.388^{\star *} \\
(0.180)\end{array}$ & $\begin{array}{l}-0.394^{* * *} \\
(0.139)\end{array}$ \\
\hline Constant & $\begin{array}{l}12.113^{* * *} \\
(0.597)\end{array}$ & $\begin{array}{l}9.218^{* * *} \\
(2.994)\end{array}$ & $\begin{array}{l}6.690^{* *} \\
(3.066)\end{array}$ & $\begin{array}{l}11.325^{* * *} \\
(2.966)\end{array}$ \\
\hline $\begin{array}{l}\text { Observations } \\
\text { R-squared }\end{array}$ & $\begin{array}{l}30,211 \\
0.124\end{array}$ & $\begin{array}{l}11,014 \\
0.133\end{array}$ & $\begin{array}{l}10,443 \\
0.113\end{array}$ & $\begin{array}{l}8,754 \\
0.088\end{array}$ \\
\hline
\end{tabular}

Notes: Debt levels are winsorized at the $99 \%$ level. Robust standard errors in parentheses. For Column 1, standard errors are clustered at the individual level. ${ }^{* * *} p<0.01,{ }^{* *} p<0.05,{ }^{*} p<0.1$ 
Table 4: Cognitive Ability and Total Debt by Age Group over Time

\begin{tabular}{|c|c|c|c|c|}
\hline VARIABLES & \begin{tabular}{l}
\multicolumn{1}{c}{$(1)$} \\
Total Debt (\$10k) \\
$56-73$
\end{tabular} & \begin{tabular}{l}
\multicolumn{1}{c}{$(2)$} \\
Total Debt (\$10k) \\
$56-61$
\end{tabular} & \begin{tabular}{l}
\multicolumn{1}{c}{$(3)$} \\
Total Debt (\$10k) \\
$62-67$
\end{tabular} & \begin{tabular}{l}
\multicolumn{1}{c}{$(4)$} \\
Total Debt (\$10k) \\
$68-73$
\end{tabular} \\
\hline Cog Ability & $\begin{array}{l}0.061^{* * *} \\
(0.014)\end{array}$ & $\begin{array}{l}0.098^{* * *} \\
(0.027)\end{array}$ & $\begin{array}{l}0.064^{* * *} \\
(0.022)\end{array}$ & $\begin{array}{l}0.021 \\
(0.020)\end{array}$ \\
\hline Cog abi * 2006 & $\begin{array}{l}0.110^{* * *} \\
(0.024)\end{array}$ & $\begin{array}{l}0.207^{* * *} \\
(0.050)\end{array}$ & $\begin{array}{l}0.060 \\
(0.039)\end{array}$ & $\begin{array}{l}0.076^{* *} \\
(0.032)\end{array}$ \\
\hline Cog abi * 2014 & $\begin{array}{l}0.180^{* * *} \\
(0.025)\end{array}$ & $\begin{array}{l}0.110^{* * *} \\
(0.042)\end{array}$ & $\begin{array}{l}0.214^{* * *} \\
(0.039)\end{array}$ & $\begin{array}{l}0.180^{* * *} \\
(0.040)\end{array}$ \\
\hline 2006 & $\begin{array}{l}0.158 \\
(0.347)\end{array}$ & $\begin{array}{l}-0.941 \\
(0.788)\end{array}$ & $\begin{array}{l}0.963^{*} \\
(0.586)\end{array}$ & $\begin{array}{l}-0.106 \\
(0.447)\end{array}$ \\
\hline 2014 & $\begin{array}{l}-1.004^{* * *} \\
(0.350)\end{array}$ & $\begin{array}{l}-0.144 \\
(0.646)\end{array}$ & $\begin{array}{l}-1.484^{* * *} \\
(0.562)\end{array}$ & $\begin{array}{l}-0.783 \\
(0.560)\end{array}$ \\
\hline Age & $\begin{array}{l}-0.218^{\star * *} \\
(0.010)\end{array}$ & $\begin{array}{l}-0.196^{\star * *} \\
(0.051)\end{array}$ & $\begin{array}{l}-0.137^{* * *} \\
(0.047)\end{array}$ & $\begin{array}{l}-0.173^{* * *} \\
(0.042)\end{array}$ \\
\hline Female & $\begin{array}{l}-0.770^{* * *} \\
(0.101)\end{array}$ & $\begin{array}{l}-0.852^{* * *} \\
(0.180)\end{array}$ & $\begin{array}{l}-0.706^{\star * *} \\
(0.167)\end{array}$ & $\begin{array}{l}-0.831^{* * *} \\
(0.156)\end{array}$ \\
\hline Married & $\begin{array}{l}1.931^{* * *} \\
(0.119)\end{array}$ & $\begin{array}{l}2.863^{* * *} \\
(0.191)\end{array}$ & $\begin{array}{l}1.548^{* * *} \\
(0.195)\end{array}$ & $\begin{array}{l}0.940^{* * *} \\
(0.156)\end{array}$ \\
\hline Num children & $\begin{array}{l}0.098^{* * *} \\
(0.020)\end{array}$ & $\begin{array}{l}0.038 \\
(0.039)\end{array}$ & $\begin{array}{l}0.122^{* * *} \\
(0.035)\end{array}$ & $\begin{array}{l}0.157^{\star * *} \\
(0.030)\end{array}$ \\
\hline White & $\begin{array}{l}0.402^{* * *} \\
(0.122)\end{array}$ & $\begin{array}{l}0.973^{* * *} \\
(0.201)\end{array}$ & $\begin{array}{l}-0.028 \\
(0.192)\end{array}$ & $\begin{array}{l}-0.431^{* *} \\
(0.185)\end{array}$ \\
\hline More than HS & $\begin{array}{l}2.881^{* * *} \\
(0.131)\end{array}$ & $\begin{array}{l}3.660^{\star * *} \\
(0.196)\end{array}$ & $\begin{array}{l}2.312^{* \star *} \\
(0.189)\end{array}$ & $\begin{array}{l}2.186^{* * *} \\
(0.176)\end{array}$ \\
\hline HHI (\$10k) & $\begin{array}{l}0.040 \\
(0.025)\end{array}$ & $\begin{array}{l}0.026 \\
(0.021)\end{array}$ & $\begin{array}{l}0.121^{* * *} \\
(0.031)\end{array}$ & $\begin{array}{l}0.056^{* *} \\
(0.025)\end{array}$ \\
\hline Poor health & $\begin{array}{l}-0.690^{* * *} \\
(0.104)\end{array}$ & $\begin{array}{l}-1.081^{* * *} \\
(0.184)\end{array}$ & $\begin{array}{l}-0.389^{* *} \\
(0.179)\end{array}$ & $\begin{array}{l}-0.402^{* * *} \\
(0.138)\end{array}$ \\
\hline Constant & $\begin{array}{l}13.793^{* \star *} \\
(0.674)\end{array}$ & $\begin{array}{l}10.923^{* * *} \\
(3.022)\end{array}$ & $\begin{array}{l}8.552^{\star \star *} \\
(3.067)\end{array}$ & $\begin{array}{l}12.681^{* \star *} \\
(2.973)\end{array}$ \\
\hline $\begin{array}{l}\text { Observations } \\
\text { R-squared }\end{array}$ & $\begin{array}{l}30,211 \\
0.125\end{array}$ & $\begin{array}{l}11,014 \\
0.134\end{array}$ & $\begin{array}{l}10,443 \\
0.115\end{array}$ & $\begin{array}{l}8,754 \\
0.090\end{array}$ \\
\hline
\end{tabular}

Notes: Debt levels are winsorized at the $99 \%$ level. Robust standard errors in parentheses. For Column 1, standard errors are clustered at the individual level. ${ }^{* * *} p<0.01,{ }^{* *} p<0.05,{ }^{*} p<0.1$ 
Table 5: Cognitive Ability and Mortgage Debt on Primary Home by Age Group over Time

\begin{tabular}{|c|c|c|c|c|}
\hline VARIABLES & \begin{tabular}{l}
\multicolumn{1}{c}{$(1)$} \\
Total Debt $(\$ 10 k)$ \\
$56-73$
\end{tabular} & \begin{tabular}{l}
\multicolumn{1}{c}{$(2)$} \\
Total Debt $(\$ 10 k)$ \\
$56-61$
\end{tabular} & \begin{tabular}{l}
\multicolumn{1}{c}{$(3)$} \\
Total Debt $(\$ 10 \mathrm{k})$ \\
$62-67$
\end{tabular} & \begin{tabular}{l}
\multicolumn{1}{c}{$(4)$} \\
Total Debt (\$10k) \\
$68-73$
\end{tabular} \\
\hline Cog Ability & $\begin{array}{l}0.043^{* * *} \\
(0.012)\end{array}$ & $\begin{array}{l}0.078^{* * *} \\
(0.023)\end{array}$ & $\begin{array}{l}0.036^{* *} \\
(0.018)\end{array}$ & $\begin{array}{l}0.022 \\
(0.017)\end{array}$ \\
\hline Cog abi * 2006 & $\begin{array}{l}0.076^{\star \star \star *} \\
(0.018)\end{array}$ & $\begin{array}{l}0.144^{* * *} \\
(0.041)\end{array}$ & $\begin{array}{l}0.057^{*} \\
(0.032)\end{array}$ & $\begin{array}{l}0.033 \\
(0.027)\end{array}$ \\
\hline Cog abi * 2014 & $\begin{array}{l}0.138^{* * *} \\
(0.020)\end{array}$ & $\begin{array}{l}0.062^{*} \\
(0.036)\end{array}$ & $\begin{array}{l}0.182^{* * *} \\
(0.032)\end{array}$ & $\begin{array}{l}0.143^{* * *} \\
(0.035)\end{array}$ \\
\hline 2006 & $\begin{array}{l}0.346 \\
(0.275)\end{array}$ & $\begin{array}{l}-0.407 \\
(0.640)\end{array}$ & $\begin{array}{l}0.838^{*} \\
(0.495)\end{array}$ & $\begin{array}{l}0.200 \\
(0.379)\end{array}$ \\
\hline 2014 & $\begin{array}{l}-0.765^{\star * *} \\
(0.294)\end{array}$ & $\begin{array}{l}0.215 \\
(0.551)\end{array}$ & $\begin{array}{l}-1.228^{* * *} \\
(0.467)\end{array}$ & $\begin{array}{l}-0.747 \\
(0.486)\end{array}$ \\
\hline Age & $\begin{array}{l}-0.176^{\star * *} \\
(0.007)\end{array}$ & $\begin{array}{l}-0.203^{\star * *} \\
(0.043)\end{array}$ & $\begin{array}{l}-0.073^{*} \\
(0.040)\end{array}$ & $\begin{array}{l}-0.176^{\star \star *} \\
(0.035)\end{array}$ \\
\hline Female & $\begin{array}{l}-0.559^{* * *} \\
(0.098)\end{array}$ & $\begin{array}{l}-0.575^{\star * *} \\
(0.152)\end{array}$ & $\begin{array}{l}-0.560^{* * *} \\
(0.140)\end{array}$ & $\begin{array}{l}-0.638^{* * *} \\
(0.131)\end{array}$ \\
\hline Married & $\begin{array}{l}1.522^{* * *} \\
(0.104)\end{array}$ & $\begin{array}{l}2.403^{\star * *} \\
(0.159)\end{array}$ & $\begin{array}{l}1.140^{* * *} \\
(0.156)\end{array}$ & $\begin{array}{l}0.665^{\star * *} \\
(0.127)\end{array}$ \\
\hline Num children & $\begin{array}{l}0.083^{* \star *} \\
(0.020)\end{array}$ & $\begin{array}{l}0.015 \\
(0.033)\end{array}$ & $\begin{array}{l}0.127^{\star \star *} \\
(0.030)\end{array}$ & $\begin{array}{l}0.123^{\star \star *} \\
(0.026)\end{array}$ \\
\hline White & $\begin{array}{l}0.200^{*} \\
(0.118)\end{array}$ & $\begin{array}{l}0.638^{* * *} \\
(0.171)\end{array}$ & $\begin{array}{l}-0.122 \\
(0.166)\end{array}$ & $\begin{array}{l}-0.477^{* * *} \\
(0.167)\end{array}$ \\
\hline More than HS & $\begin{array}{l}2.240^{* * *} \\
(0.115)\end{array}$ & $\begin{array}{l}2.892^{* * *} \\
(0.164)\end{array}$ & $\begin{array}{l}1.791^{* * *} \\
(0.153)\end{array}$ & $\begin{array}{l}1.670^{* * *} \\
(0.142)\end{array}$ \\
\hline HHI (\$10k) & $\begin{array}{l}0.028 \\
(0.018)\end{array}$ & $\begin{array}{l}0.019 \\
(0.016)\end{array}$ & $\begin{array}{l}0.083^{* * *} \\
(0.022)\end{array}$ & $\begin{array}{l}0.036^{* *} \\
(0.017)\end{array}$ \\
\hline Poor health & $\begin{array}{l}-0.651^{* * *} \\
(0.089)\end{array}$ & $\begin{array}{l}-1.023^{* * *} \\
(0.154)\end{array}$ & $\begin{array}{l}-0.521^{* * *} \\
(0.146)\end{array}$ & $\begin{array}{l}-0.247^{* *} \\
(0.119)\end{array}$ \\
\hline Constant & $\begin{array}{l}11.111^{\text {*** }} \\
(0.531)\end{array}$ & $\begin{array}{l}11.352^{* * *} \\
(2.537)\end{array}$ & $\begin{array}{l}4.570^{*} \\
(2.599)\end{array}$ & $\begin{array}{l}12.851^{\text {*** }} \\
(2.503)\end{array}$ \\
\hline $\begin{array}{l}\text { Observations } \\
\text { R-squared }\end{array}$ & $\begin{array}{l}30,211 \\
0.107\end{array}$ & $\begin{array}{l}11,014 \\
0.118\end{array}$ & $\begin{array}{l}10,443 \\
0.097\end{array}$ & $\begin{array}{l}8,754 \\
0.071\end{array}$ \\
\hline
\end{tabular}

Notes: Debt levels are winsorized at the $99 \%$ level. Robust standard errors in parentheses. For Column 1, standard errors are clustered at the individual level. ${ }^{* * *} p<0.01,{ }^{* *} p<0.05,{ }^{*} p<0.1$ 
Table 6: Cognitive Ability, Home Price Changes, and Mortgage Debt

\begin{tabular}{|c|c|c|c|}
\hline VARIABLES & $\begin{array}{c}(1) \\
\text { Total Debt (\$10k) }\end{array}$ & $\begin{array}{c}(2) \\
\text { Total Debt }(\$ 10 \mathrm{k}) \\
\end{array}$ & $\begin{array}{c}(3) \\
\text { Total Debt }(\$ 10 \mathrm{k}) \\
\end{array}$ \\
\hline Cog Abi * Change HVI & & $\begin{array}{l}0.003^{* *} \\
(0.001)\end{array}$ & $\begin{array}{l}0.003 \\
(0.002)\end{array}$ \\
\hline $\begin{array}{l}\text { Cog Abi * Change HVI * } \\
2006\end{array}$ & & & -0.001 \\
\hline $\begin{array}{l}\text { Cog Abi * Change HVI * } \\
2014\end{array}$ & & & $\begin{array}{l}(0.003) \\
0.002\end{array}$ \\
\hline & & & $(0.003)$ \\
\hline Cog abi * 2006 & & & $\begin{array}{l}0.073^{* *} \\
(0.033)\end{array}$ \\
\hline Cog abi * 2014 & & & $\begin{array}{l}0.117^{* * *} \\
(0.028)\end{array}$ \\
\hline Change HVI * 2006 & & & $\begin{array}{l}-0.007 \\
(0.046)\end{array}$ \\
\hline Change HVI * 2014 & & & $\begin{array}{l}0.024 \\
(0.050)\end{array}$ \\
\hline Cog Ability & $\begin{array}{l}0.124^{* * *} \\
(0.013)\end{array}$ & $\begin{array}{l}0.102^{* * *} \\
(0.015)\end{array}$ & $\begin{array}{l}0.040^{* *} \\
(0.017)\end{array}$ \\
\hline Change HVI & $\begin{array}{l}0.042^{* * *} \\
(0.006)\end{array}$ & $\begin{array}{l}-0.007 \\
(0.019)\end{array}$ & $\begin{array}{l}-0.014 \\
(0.031)\end{array}$ \\
\hline 2006 & $\begin{array}{l}1.710^{* * *} \\
(0.108)\end{array}$ & $\begin{array}{l}1.713^{* * *} \\
(0.108)\end{array}$ & $\begin{array}{l}0.720 \\
(0.510)\end{array}$ \\
\hline 2014 & $\begin{array}{l}1.562^{* * *} \\
(0.125)\end{array}$ & $\begin{array}{l}1.557^{\star * *} \\
(0.125)\end{array}$ & $\begin{array}{l}-0.726^{*} \\
(0.412)\end{array}$ \\
\hline Age & $\begin{array}{l}-0.205^{\star \star \star} \\
(0.009)\end{array}$ & $\begin{array}{l}-0.205^{\star \star \star} \\
(0.009)\end{array}$ & $\begin{array}{l}-0.207^{\star * \star} \\
(0.009)\end{array}$ \\
\hline Female & $\begin{array}{l}-0.672^{* \star *} \\
(0.121)\end{array}$ & $\begin{array}{l}-0.671^{* * *} \\
(0.121)\end{array}$ & $\begin{array}{l}-0.668^{* * \star} \\
(0.120)\end{array}$ \\
\hline Married & $\begin{array}{l}1.816^{* * *} \\
(0.126)\end{array}$ & $\begin{array}{l}1.819^{* * *} \\
(0.126)\end{array}$ & $\begin{array}{l}1.800^{* \star *} \\
(0.126)\end{array}$ \\
\hline \# children & $\begin{array}{l}0.104^{* * *} \\
(0.026)\end{array}$ & $\begin{array}{l}0.104^{* \star *} \\
(0.026)\end{array}$ & $\begin{array}{l}0.103^{* \star *} \\
(0.026)\end{array}$ \\
\hline White & $\begin{array}{l}0.114 \\
(0.152)\end{array}$ & $\begin{array}{l}0.111 \\
(0.152)\end{array}$ & $\begin{array}{l}0.088 \\
(0.151)\end{array}$ \\
\hline More than HS & $\begin{array}{l}2.341^{* * *} \\
(0.133)\end{array}$ & $\begin{array}{l}2.340^{* * *} \\
(0.133)\end{array}$ & $\begin{array}{l}2.319^{* \star *} \\
(0.132)\end{array}$ \\
\hline Household Income (\$10k) & $\begin{array}{l}0.027 \\
(0.019)\end{array}$ & $\begin{array}{l}0.027 \\
(0.019)\end{array}$ & $\begin{array}{l}0.027 \\
(0.019)\end{array}$ \\
\hline Poor health & $\begin{array}{l}-0.669^{\star \star \star} \\
(0.112)\end{array}$ & $\begin{array}{l}-0.669^{* * *} \\
(0.112)\end{array}$ & $\begin{array}{l}-0.666^{* * *} \\
(0.111)\end{array}$ \\
\hline Constant & $\begin{array}{l}11.582^{\star * *} \\
(0.629)\end{array}$ & $\begin{array}{l}11.941^{* * *} \\
(0.631)\end{array}$ & $\begin{array}{l}13.168^{* * \star} \\
(0.674)\end{array}$ \\
\hline $\begin{array}{l}\text { Observations } \\
\text { R-squared }\end{array}$ & $\begin{array}{l}23,264 \\
0.110 \\
\end{array}$ & $\begin{array}{l}23,264 \\
0.110 \\
\end{array}$ & $\begin{array}{l}23,264 \\
0.112 \\
\end{array}$ \\
\hline
\end{tabular}

Notes: Debt levels are winsorized at the $99 \%$ level. Change HVI denotes the one-year percentage change in the respondent's home value index. Robust standard errors in parentheses. Standard errors are clustered at the individual level. ${ }^{* *} p<0.01,{ }^{* *} p<0.05,{ }^{*} p<0.1$. 
Table 7: Cognitive Ability and Other Home Loans by Age Group over Time

\begin{tabular}{|c|c|c|c|c|}
\hline VARIABLES & \begin{tabular}{l}
\multicolumn{1}{c}{$(1)$} \\
Total Debt $(\$ 10 k)$ \\
$56-73$
\end{tabular} & \begin{tabular}{l}
\multicolumn{1}{c}{$(2)$} \\
Total Debt $(\$ 10 k)$ \\
$56-61$
\end{tabular} & $\begin{array}{l}(3) \\
\text { Total Debt (\$10k) } \\
62-67\end{array}$ & $\begin{array}{l}\text { (4) } \\
\text { Total Debt (\$10k) } \\
68-73\end{array}$ \\
\hline Cog Ability & $\begin{array}{l}0.002 \\
(0.002)\end{array}$ & $\begin{array}{l}0.002 \\
(0.005)\end{array}$ & $\begin{array}{l}0.003 \\
(0.004)\end{array}$ & $\begin{array}{l}-0.004 \\
(0.003)\end{array}$ \\
\hline $\begin{array}{l}\text { Cog abi * } \\
2006\end{array}$ & $\begin{array}{l}0.018^{* * *} \\
(0.004)\end{array}$ & $\begin{array}{l}0.025^{* \star *} \\
(0.009)\end{array}$ & $\begin{array}{l}0.011^{*} \\
(0.006)\end{array}$ & $\begin{array}{l}0.021^{* * *} \\
(0.006)\end{array}$ \\
\hline $\begin{array}{l}\text { Cog abi * } \\
2014\end{array}$ & $0.013^{* * *}$ & $0.017^{* * *}$ & 0.009 & $0.017^{* \star *}$ \\
\hline & $(0.004)$ & $(0.006)$ & $(0.006)$ & $(0.006)$ \\
\hline 2006 & $\begin{array}{l}-0.118^{* *} \\
(0.059)\end{array}$ & $\begin{array}{l}-0.218 \\
(0.140)\end{array}$ & $\begin{array}{l}-0.055 \\
(0.099)\end{array}$ & $\begin{array}{l}-0.139^{*} \\
(0.078)\end{array}$ \\
\hline 2014 & $\begin{array}{l}-0.122^{* *} \\
(0.054)\end{array}$ & $\begin{array}{l}-0.237^{* *} \\
(0.098)\end{array}$ & $\begin{array}{l}-0.097 \\
(0.090)\end{array}$ & $\begin{array}{l}-0.076 \\
(0.093)\end{array}$ \\
\hline Age & $\begin{array}{l}-0.008^{* * *} \\
(0.001)\end{array}$ & $\begin{array}{l}0.008 \\
(0.008)\end{array}$ & $\begin{array}{l}-0.006 \\
(0.007)\end{array}$ & $\begin{array}{l}0.002 \\
(0.007)\end{array}$ \\
\hline Female & $\begin{array}{l}-0.025^{*} \\
(0.015)\end{array}$ & $\begin{array}{l}-0.033 \\
(0.027)\end{array}$ & $\begin{array}{l}-0.005 \\
(0.026)\end{array}$ & $\begin{array}{l}-0.044^{*} \\
(0.027)\end{array}$ \\
\hline Married & $\begin{array}{l}0.206^{* * *} \\
(0.014)\end{array}$ & $\begin{array}{l}0.255^{* * *} \\
(0.026)\end{array}$ & $\begin{array}{l}0.204^{* * *} \\
(0.023)\end{array}$ & $\begin{array}{l}0.137^{* * *} \\
(0.024)\end{array}$ \\
\hline $\begin{array}{l}\text { Num } \\
\text { children }\end{array}$ & -0.003 & $-0.018^{* * *}$ & -0.001 & 0.008 \\
\hline & $(0.003)$ & $(0.006)$ & $(0.005)$ & $(0.005)$ \\
\hline White & $\begin{array}{l}0.066^{* \star *} \\
(0.017)\end{array}$ & $\begin{array}{l}0.059^{* *} \\
(0.029)\end{array}$ & $\begin{array}{l}0.071^{* * *} \\
(0.027)\end{array}$ & $\begin{array}{l}0.040 \\
(0.028)\end{array}$ \\
\hline $\begin{array}{l}\text { More than } \\
\text { HS }\end{array}$ & $0.132^{* * *}$ & $0.117^{* \star \star}$ & $0.102^{\star \star \star}$ & $0.179^{\star \star \star}$ \\
\hline & $(0.017)$ & $(0.028)$ & $(0.028)$ & $(0.030)$ \\
\hline HHI (\$10k) & $\begin{array}{l}0.001 \\
(0.001)\end{array}$ & $\begin{array}{l}0.001 \\
(0.001)\end{array}$ & $\begin{array}{l}0.005^{* *} \\
(0.002)\end{array}$ & $\begin{array}{l}0.001 \\
(0.001)\end{array}$ \\
\hline Poor health & $\begin{array}{l}-0.087^{* * *} \\
(0.014)\end{array}$ & $\begin{array}{l}-0.094^{* * *} \\
(0.027)\end{array}$ & $\begin{array}{l}-0.052^{* *} \\
(0.025)\end{array}$ & $\begin{array}{l}-0.111^{* * *} \\
(0.021)\end{array}$ \\
\hline Constant & $\begin{array}{l}0.562^{* * *} \\
(0.106)\end{array}$ & $\begin{array}{l}-0.347 \\
(0.467)\end{array}$ & $\begin{array}{l}0.341 \\
(0.468)\end{array}$ & $\begin{array}{l}-0.133 \\
(0.521)\end{array}$ \\
\hline $\begin{array}{l}\text { Observation } \\
\text { s }\end{array}$ & 30,211 & 11,014 & 10,443 & 8,754 \\
\hline R-squared & 0.024 & 0.027 & 0.021 & 0.026 \\
\hline
\end{tabular}

Notes: Debt levels are winsorized at the $99 \%$ level. Robust standard errors in parentheses. For Column 1, standard errors are clustered at the individual level. ${ }^{* * *} p<0.01,{ }^{* *} p<0.05,{ }^{*} p<0.1$ 
Table 8: Cognitive Ability and Other Debt by Age Group over Time

\begin{tabular}{|c|c|c|c|c|}
\hline VARIABLES & \begin{tabular}{l}
\multicolumn{1}{c}{$(1)$} \\
Total Debt $(\$ 10 k)$ \\
$56-73$
\end{tabular} & \begin{tabular}{l}
\multicolumn{1}{c}{$(2)$} \\
Total Debt $(\$ 10 k)$ \\
$56-61$
\end{tabular} & $\begin{array}{l}\text { (3) } \\
\text { Total Debt }(\$ 10 k) \\
62-67\end{array}$ & $\begin{array}{l}\text { Total Debt (\$10k) } \\
\text { Total } \\
68-73\end{array}$ \\
\hline Cog Ability & $\begin{array}{l}0.006^{* * *} \\
(0.002)\end{array}$ & $\begin{array}{l}0.005 \\
(0.004)\end{array}$ & $\begin{array}{l}0.009^{* * *} \\
(0.003)\end{array}$ & $\begin{array}{l}0.004 \\
(0.003)\end{array}$ \\
\hline Cog abi * 2006 & $\begin{array}{l}0.005^{*} \\
(0.003)\end{array}$ & $\begin{array}{l}0.016^{* *} \\
(0.007)\end{array}$ & $\begin{array}{l}-0.005 \\
(0.005)\end{array}$ & $\begin{array}{l}0.007^{*} \\
(0.004)\end{array}$ \\
\hline Cog abi * 2014 & $\begin{array}{l}0.013^{* * *} \\
(0.003)\end{array}$ & $\begin{array}{l}0.018^{* * *} \\
(0.006)\end{array}$ & $\begin{array}{l}0.007 \\
(0.006)\end{array}$ & $\begin{array}{l}0.013^{* * *} \\
(0.004)\end{array}$ \\
\hline 2006 & $\begin{array}{l}-0.018 \\
(0.046)\end{array}$ & $\begin{array}{l}-0.160 \\
(0.109)\end{array}$ & $\begin{array}{l}0.103 \\
(0.074)\end{array}$ & $\begin{array}{l}-0.052 \\
(0.056)\end{array}$ \\
\hline 2014 & $\begin{array}{l}-0.055 \\
(0.051)\end{array}$ & $\begin{array}{l}-0.086 \\
(0.101)\end{array}$ & $\begin{array}{l}-0.003 \\
(0.088)\end{array}$ & $\begin{array}{l}-0.044 \\
(0.065)\end{array}$ \\
\hline Age & $\begin{array}{l}-0.020^{* * *} \\
(0.001)\end{array}$ & $\begin{array}{l}-0.020^{* * *} \\
(0.007)\end{array}$ & $\begin{array}{l}-0.014^{* * *} \\
(0.005)\end{array}$ & $\begin{array}{l}-0.012^{* *} \\
(0.005)\end{array}$ \\
\hline Female & $\begin{array}{l}-0.078^{* * *} \\
(0.013)\end{array}$ & $\begin{array}{l}-0.119^{* * *} \\
(0.025)\end{array}$ & $\begin{array}{l}-0.063^{* * *} \\
(0.021)\end{array}$ & $\begin{array}{l}-0.050^{* * *} \\
(0.019)\end{array}$ \\
\hline Married & $\begin{array}{l}0.051^{* * *} \\
(0.013)\end{array}$ & $\begin{array}{l}0.061^{* *} \\
(0.026)\end{array}$ & $\begin{array}{l}0.061^{* * *} \\
(0.021)\end{array}$ & $\begin{array}{l}0.033^{*} \\
(0.020)\end{array}$ \\
\hline Num children & $\begin{array}{l}0.011^{* * *} \\
(0.003)\end{array}$ & $\begin{array}{l}0.023^{* * *} \\
(0.006)\end{array}$ & $\begin{array}{l}0.003 \\
(0.005)\end{array}$ & $\begin{array}{l}0.008^{* *} \\
(0.004)\end{array}$ \\
\hline White & $\begin{array}{l}-0.051^{\text {*** }} \\
(0.016)\end{array}$ & $\begin{array}{l}0.004 \\
(0.028)\end{array}$ & $\begin{array}{l}-0.069^{\star * *} \\
(0.026)\end{array}$ & $\begin{array}{l}-0.123^{* * *} \\
(0.026)\end{array}$ \\
\hline More than HS & $\begin{array}{l}0.098^{* * *} \\
(0.013)\end{array}$ & $\begin{array}{l}0.157^{* \star *} \\
(0.026)\end{array}$ & $\begin{array}{l}0.087^{* * *} \\
(0.022)\end{array}$ & $\begin{array}{l}0.034^{*} \\
(0.020)\end{array}$ \\
\hline $\mathrm{HHI}(\$ 10 \mathrm{k})$ & $\begin{array}{l}0.000 \\
(0.000)\end{array}$ & $\begin{array}{l}-0.000 \\
(0.000)\end{array}$ & $\begin{array}{l}-0.000 \\
(0.001)\end{array}$ & $\begin{array}{l}0.001 \\
(0.001)\end{array}$ \\
\hline Poor health & $\begin{array}{l}0.092^{* * *} \\
(0.015)\end{array}$ & $\begin{array}{l}0.117^{* * *} \\
(0.029)\end{array}$ & $\begin{array}{l}0.101^{* * *} \\
(0.024)\end{array}$ & $\begin{array}{l}0.061^{* * *} \\
(0.019)\end{array}$ \\
\hline Constant & $\begin{array}{l}1.430 * * * \\
(0.087)\end{array}$ & $\begin{array}{l}1.383^{* * *} \\
(0.420)\end{array}$ & $\begin{array}{l}1.069^{* * *} \\
(0.355)\end{array}$ & $\begin{array}{l}1.026 * * * \\
(0.348)\end{array}$ \\
\hline $\begin{array}{l}\text { Observations } \\
\text { R-squared }\end{array}$ & $\begin{array}{l}30,211 \\
0.024\end{array}$ & $\begin{array}{l}11,014 \\
0.019\end{array}$ & $\begin{array}{l}10,443 \\
0.011\end{array}$ & $\begin{array}{l}8,754 \\
0.015\end{array}$ \\
\hline
\end{tabular}

Notes: Debt levels are winsorized at the 99\% level. Robust standard errors in parentheses. For Column 1 , standard errors are clustered at the individual level. ${ }^{* * *} p<0.01,{ }^{* *} p<0.05,{ }^{*} p<0.1$ 
Table 9: Cognitive Ability and Net Total Wealth by Age Group over Time

\begin{tabular}{|c|c|c|c|c|}
\hline VARIABLES & \begin{tabular}{l}
\multicolumn{1}{c}{$(1)$} \\
Net Wealth (\$10k) \\
$56-73$
\end{tabular} & \begin{tabular}{l}
\multicolumn{1}{c}{$(2)$} \\
Net Wealth (\$10k) \\
$56-61$
\end{tabular} & \begin{tabular}{l}
\multicolumn{1}{c}{$(3)$} \\
Net Wealth $(\$ 10 k)$ \\
$62-67$
\end{tabular} & \begin{tabular}{l}
\multicolumn{1}{c}{$(4)$} \\
Net Wealth (\$10k) \\
$68-73$
\end{tabular} \\
\hline Cog Ability & $\begin{array}{l}1.435^{\star * *} \\
(0.144)\end{array}$ & $\begin{array}{l}1.510^{* * *} \\
(0.226)\end{array}$ & $\begin{array}{l}1.153^{* * *} \\
(0.234)\end{array}$ & $\begin{array}{l}1.224^{* * *} \\
(0.264)\end{array}$ \\
\hline Cog abi * 2006 & $\begin{array}{l}0.562^{* *} \\
(0.218)\end{array}$ & $\begin{array}{l}0.013 \\
(0.388)\end{array}$ & $\begin{array}{l}0.794^{* *} \\
(0.358)\end{array}$ & $\begin{array}{l}0.580 \\
(0.374)\end{array}$ \\
\hline Cog abi * 2014 & $\begin{array}{l}-0.540^{* *} \\
(0.230)\end{array}$ & $\begin{array}{l}-0.874^{* * *} \\
(0.308)\end{array}$ & $\begin{array}{l}-0.782^{* *} \\
(0.347)\end{array}$ & $\begin{array}{l}-0.085 \\
(0.435)\end{array}$ \\
\hline 2006 & $\begin{array}{l}-1.441 \\
(3.139)\end{array}$ & $\begin{array}{l}5.014 \\
(6.077)\end{array}$ & $\begin{array}{l}-7.194 \\
(5.231)\end{array}$ & $\begin{array}{l}0.683 \\
(5.148)\end{array}$ \\
\hline 2014 & $\begin{array}{l}1.790 \\
(2.944)\end{array}$ & $\begin{array}{l}5.248 \\
(4.490)\end{array}$ & $\begin{array}{l}-0.984 \\
(4.697)\end{array}$ & $\begin{array}{l}-1.345 \\
(5.799)\end{array}$ \\
\hline Age & $\begin{array}{l}1.435^{\star \star \star} \\
(0.097)\end{array}$ & $\begin{array}{l}2.378^{* \star *} \\
(0.374)\end{array}$ & $\begin{array}{l}1.444^{\star * *} \\
(0.400)\end{array}$ & $\begin{array}{l}0.941^{* *} \\
(0.461)\end{array}$ \\
\hline Female & $\begin{array}{l}0.059 \\
(0.950)\end{array}$ & $\begin{array}{l}2.242^{*} \\
(1.357)\end{array}$ & $\begin{array}{l}1.716 \\
(1.435)\end{array}$ & $\begin{array}{l}-1.866 \\
(1.773)\end{array}$ \\
\hline Married & $\begin{array}{l}23.907^{* * *} \\
(1.507)\end{array}$ & $\begin{array}{l}21.794^{* * *} \\
(1.654)\end{array}$ & $\begin{array}{l}19.610^{* * *} \\
(2.078)\end{array}$ & $\begin{array}{l}24.604^{* * *} \\
(2.154)\end{array}$ \\
\hline Num children & $\begin{array}{l}-1.773^{\star * *} \\
(0.167)\end{array}$ & $\begin{array}{l}-1.870^{* * *} \\
(0.276)\end{array}$ & $\begin{array}{l}-1.479^{* * *} \\
(0.268)\end{array}$ & $\begin{array}{l}-1.955^{\star * *} \\
(0.311)\end{array}$ \\
\hline White & $\begin{array}{l}17.943^{* * *} \\
(1.068)\end{array}$ & $\begin{array}{l}16.499^{* * *} \\
(1.312)\end{array}$ & $\begin{array}{l}17.340^{* * *} \\
(1.177)\end{array}$ & $\begin{array}{l}18.144^{* * *} \\
(1.714)\end{array}$ \\
\hline More than HS & $\begin{array}{l}27.914^{* * *} \\
(1.721)\end{array}$ & $\begin{array}{l}23.918^{* * *} \\
(1.757)\end{array}$ & $\begin{array}{l}23.354^{* * *} \\
(1.982)\end{array}$ & $\begin{array}{l}31.115^{* * *} \\
(2.394)\end{array}$ \\
\hline HHI (\$10k) & $\begin{array}{l}0.924^{* *} \\
(0.432)\end{array}$ & $\begin{array}{l}0.587^{* *} \\
(0.298)\end{array}$ & $\begin{array}{l}2.599^{* * *} \\
(0.481)\end{array}$ & $\begin{array}{l}1.925^{* * *} \\
(0.584)\end{array}$ \\
\hline Poor health & $\begin{array}{l}-13.924^{* * *} \\
(1.086)\end{array}$ & $\begin{array}{l}-14.203^{* * *} \\
(1.332)\end{array}$ & $\begin{array}{l}-10.701^{* * *} \\
(1.640)\end{array}$ & $\begin{array}{l}-14.300^{\star * *} \\
(1.645)\end{array}$ \\
\hline Constant & $\begin{array}{l}-105.852^{* * *} \\
(6.750)\end{array}$ & $\begin{array}{l}-154.848^{\star * *} \\
(22.428)\end{array}$ & $\begin{array}{l}-106.612^{* * *} \\
(26.257)\end{array}$ & $\begin{array}{l}-75.813^{\star *} \\
(32.895)\end{array}$ \\
\hline $\begin{array}{l}\text { Observations } \\
\text { R-squared }\end{array}$ & $\begin{array}{l}30,211 \\
0.211\end{array}$ & $\begin{array}{l}11,014 \\
0.197\end{array}$ & $\begin{array}{l}10,443 \\
0.287\end{array}$ & $\begin{array}{l}8,754 \\
0.232\end{array}$ \\
\hline
\end{tabular}

Notes: Wealth levels are winsorized at the 99\% level. Robust standard errors in parentheses. For Column 1, standard errors are clustered at the individual level. ${ }^{* * *} p<0.01,{ }^{* *} p<0.05,{ }^{*} p<0.1$ 
Table 10: Cognitive Ability and Debt/Assets > 0.5

\begin{tabular}{|c|c|c|c|c|}
\hline VARIABLES & $56-73^{(1)}$ & $56-61^{(2)}$ & $\begin{array}{r}(3) \\
62-67^{(3)}\end{array}$ & $68-73^{(4)}$ \\
\hline Cog Ability & $\begin{array}{l}-0.001 \\
(0.001)\end{array}$ & $\begin{array}{l}-0.003^{* *} \\
(0.001)\end{array}$ & $\begin{array}{l}0.002^{* *} \\
(0.001)\end{array}$ & $\begin{array}{l}-0.001 \\
(0.001)\end{array}$ \\
\hline Cog abi * 2006 & $\begin{array}{l}0.001 \\
(0.001)\end{array}$ & $\begin{array}{l}0.004^{*} \\
(0.002)\end{array}$ & $\begin{array}{l}-0.003^{* *} \\
(0.002)\end{array}$ & $\begin{array}{l}0.001 \\
(0.001)\end{array}$ \\
\hline Cog abi * 2014 & $\begin{array}{l}0.005^{\star * *} \\
(0.001)\end{array}$ & $\begin{array}{l}0.006^{* * *} \\
(0.002)\end{array}$ & $\begin{array}{l}0.003 \\
(0.002)\end{array}$ & $\begin{array}{l}0.005^{* * *} \\
(0.002)\end{array}$ \\
\hline 2006 & $\begin{array}{l}0.021 \\
(0.016)\end{array}$ & $\begin{array}{l}-0.021 \\
(0.036)\end{array}$ & $\begin{array}{l}0.092^{* * *} \\
(0.028)\end{array}$ & $\begin{array}{l}-0.008 \\
(0.024)\end{array}$ \\
\hline 2014 & $\begin{array}{l}0.012 \\
(0.018)\end{array}$ & $\begin{array}{l}0.008 \\
(0.034)\end{array}$ & $\begin{array}{l}0.043 \\
(0.029)\end{array}$ & $\begin{array}{l}-0.009 \\
(0.029)\end{array}$ \\
\hline Age & $\begin{array}{l}-0.008^{* * *} \\
(0.000)\end{array}$ & $\begin{array}{l}-0.010^{* \star *} \\
(0.002)\end{array}$ & $\begin{array}{l}-0.005^{\star \star \star} \\
(0.002)\end{array}$ & $\begin{array}{l}-0.005^{\star * \star} \\
(0.002)\end{array}$ \\
\hline Female & $\begin{array}{l}-0.010^{* *} \\
(0.004)\end{array}$ & $\begin{array}{l}-0.017^{* *} \\
(0.007)\end{array}$ & $\begin{array}{l}-0.004 \\
(0.006)\end{array}$ & $\begin{array}{l}-0.011^{*} \\
(0.006)\end{array}$ \\
\hline Married & $\begin{array}{l}-0.040^{* * *} \\
(0.005)\end{array}$ & $\begin{array}{l}-0.045^{\star * *} \\
(0.008)\end{array}$ & $\begin{array}{l}-0.041^{* * *} \\
(0.007)\end{array}$ & $\begin{array}{l}-0.028^{* * *} \\
(0.007)\end{array}$ \\
\hline Num children & $\begin{array}{l}0.008^{* * *} \\
(0.001)\end{array}$ & $\begin{array}{l}0.008^{* * *} \\
(0.002)\end{array}$ & $\begin{array}{l}0.007^{* * *} \\
(0.002)\end{array}$ & $\begin{array}{l}0.008^{* * *} \\
(0.002)\end{array}$ \\
\hline White & $\begin{array}{l}-0.047^{* * *} \\
(0.006)\end{array}$ & $\begin{array}{l}-0.028^{* * *} \\
(0.009)\end{array}$ & $\begin{array}{l}-0.056^{* * *} \\
(0.009)\end{array}$ & $\begin{array}{l}-0.062^{* * *} \\
(0.010)\end{array}$ \\
\hline More than HS & $\begin{array}{l}-0.007^{*} \\
(0.004)\end{array}$ & $\begin{array}{l}0.005 \\
(0.008)\end{array}$ & $\begin{array}{l}-0.011 \\
(0.007)\end{array}$ & $\begin{array}{l}-0.016^{* * *} \\
(0.006)\end{array}$ \\
\hline HHI (\$10k) & $\begin{array}{l}-0.001^{* *} \\
(0.000)\end{array}$ & $\begin{array}{l}-0.000^{*} \\
(0.000)\end{array}$ & $\begin{array}{l}-0.001^{* * *} \\
(0.000)\end{array}$ & $\begin{array}{l}-0.001^{* * *} \\
(0.000)\end{array}$ \\
\hline Poor health & $\begin{array}{l}0.052^{* * *} \\
(0.005)\end{array}$ & $\begin{array}{l}0.064^{* * *} \\
(0.009)\end{array}$ & $\begin{array}{l}0.055^{* * *} \\
(0.008)\end{array}$ & $\begin{array}{l}0.033^{* * *} \\
(0.007)\end{array}$ \\
\hline Constant & $\begin{array}{l}0.631^{* * *} \\
(0.027)\end{array}$ & $\begin{array}{l}0.781^{* * *} \\
(0.127)\end{array}$ & $\begin{array}{l}0.415^{\star \star *} \\
(0.119)\end{array}$ & $\begin{array}{l}0.492^{* * *} \\
(0.121)\end{array}$ \\
\hline $\begin{array}{l}\text { Observations } \\
\text { R-squared }\end{array}$ & $\begin{array}{l}30,211 \\
0.048\end{array}$ & $\begin{array}{l}11,014 \\
0.035\end{array}$ & $\begin{array}{l}10,443 \\
0.040\end{array}$ & $\begin{array}{l}8,754 \\
0.036\end{array}$ \\
\hline
\end{tabular}

Notes: Wealth levels are winsorized at the $99 \%$ level. Robust standard errors in parentheses.

For Column 1, standard errors are clustered at the individual level. ${ }^{* * *} p<0.01,{ }^{* *} p<0.05$, * $p<0.1$ 
Table 11: Cognitive Ability and Liquid Wealth

\begin{tabular}{|c|c|c|c|c|}
\hline VARIABLES & $\begin{array}{l}(1) \\
\text { Total Wealth (\$10k) } \\
56-73\end{array}$ & $\begin{array}{l}(2) \\
\text { Total Wealth (\$10k) } \\
56-61\end{array}$ & $\begin{array}{l}(3) \\
\text { Total Wealth (\$10k) } \\
62-67\end{array}$ & $\begin{array}{l}(4) \\
\text { Total Wealth (\$10k) } \\
68-73\end{array}$ \\
\hline Cog Ability & $\begin{array}{l}0.593^{* * *} \\
(0.061)\end{array}$ & $\begin{array}{l}0.538^{* * *} \\
(0.086)\end{array}$ & $\begin{array}{l}0.528^{* * *} \\
(0.101)\end{array}$ & $\begin{array}{l}0.679^{* * *} \\
(0.125)\end{array}$ \\
\hline Cog abi * 2006 & $\begin{array}{l}-0.141^{*} \\
(0.077)\end{array}$ & $\begin{array}{l}-0.178 \\
(0.140)\end{array}$ & $\begin{array}{l}-0.155 \\
(0.138)\end{array}$ & $\begin{array}{l}-0.283^{*} \\
(0.170)\end{array}$ \\
\hline Cog abi * 2014 & $\begin{array}{l}-0.378^{\star * *} \\
(0.092)\end{array}$ & $\begin{array}{l}-0.321^{* * *} \\
(0.120)\end{array}$ & $\begin{array}{l}-0.463^{* * *} \\
(0.141)\end{array}$ & $\begin{array}{l}-0.599^{* * *} \\
(0.180)\end{array}$ \\
\hline 2006 & $\begin{array}{l}1.146 \\
(1.124)\end{array}$ & $\begin{array}{l}1.272 \\
(2.141)\end{array}$ & $\begin{array}{l}0.120 \\
(1.988)\end{array}$ & $\begin{array}{l}3.965^{*} \\
(2.309)\end{array}$ \\
\hline 2014 & $\begin{array}{l}1.981^{*} \\
(1.188)\end{array}$ & $\begin{array}{l}1.869 \\
(1.692)\end{array}$ & $\begin{array}{l}1.037 \\
(1.933)\end{array}$ & $\begin{array}{l}4.127^{*} \\
(2.485)\end{array}$ \\
\hline Age & $\begin{array}{l}0.549^{* * *} \\
(0.036)\end{array}$ & $\begin{array}{l}0.621^{* * *} \\
(0.143)\end{array}$ & $\begin{array}{l}0.609^{* * *} \\
(0.157)\end{array}$ & $\begin{array}{l}0.619^{* * *} \\
(0.190)\end{array}$ \\
\hline Female & $\begin{array}{l}0.417 \\
(0.428)\end{array}$ & $\begin{array}{l}0.612 \\
(0.519)\end{array}$ & $\begin{array}{l}1.174^{* *} \\
(0.558)\end{array}$ & $\begin{array}{l}0.393 \\
(0.724)\end{array}$ \\
\hline Married & $\begin{array}{l}4.852^{* * *} \\
(0.586)\end{array}$ & $\begin{array}{l}4.220^{* * *} \\
(0.628)\end{array}$ & $\begin{array}{l}3.243^{* * *} \\
(0.684)\end{array}$ & $\begin{array}{l}5.216^{* * *} \\
(0.746)\end{array}$ \\
\hline Num children & $\begin{array}{l}-0.645^{\star * *} \\
(0.078)\end{array}$ & $\begin{array}{l}-0.629^{* * *} \\
(0.102)\end{array}$ & $\begin{array}{l}-0.471^{* * *} \\
(0.107)\end{array}$ & $\begin{array}{l}-0.817^{* * *} \\
(0.133)\end{array}$ \\
\hline White & $\begin{array}{l}5.730^{* * *} \\
(0.420)\end{array}$ & $\begin{array}{l}5.126^{* * *} \\
(0.482)\end{array}$ & $\begin{array}{l}5.108^{* * *} \\
(0.459)\end{array}$ & $\begin{array}{l}6.821^{* * *} \\
(0.588)\end{array}$ \\
\hline More than HS & $\begin{array}{l}9.048^{* \star *} \\
(0.680)\end{array}$ & $\begin{array}{l}7.026^{* * *} \\
(0.647)\end{array}$ & $\begin{array}{l}7.345^{\star * *} \\
(0.688)\end{array}$ & $\begin{array}{l}10.982^{* * *} \\
(0.897)\end{array}$ \\
\hline HHI (\$10k) & $\begin{array}{l}0.289^{*} \\
(0.158)\end{array}$ & $\begin{array}{l}0.166 \\
(0.110)\end{array}$ & $\begin{array}{l}0.868^{* \star *} \\
(0.140)\end{array}$ & $\begin{array}{l}0.689^{* * *} \\
(0.169)\end{array}$ \\
\hline Poor health & $\begin{array}{l}-3.671^{* * *} \\
(0.415)\end{array}$ & $\begin{array}{l}-3.522^{* * *} \\
(0.479)\end{array}$ & $\begin{array}{l}-2.400^{* * *} \\
(0.556)\end{array}$ & $\begin{array}{l}-4.266^{* * *} \\
(0.613)\end{array}$ \\
\hline Constant & $\begin{array}{l}-41.467^{* * *} \\
(2.618)\end{array}$ & $\begin{array}{l}-42.299^{\star * *} \\
(8.547)\end{array}$ & $\begin{array}{l}-46.020^{* * *} \\
(10.431)\end{array}$ & $\begin{array}{l}-50.887^{* * *} \\
(13.631)\end{array}$ \\
\hline $\begin{array}{l}\text { Observations } \\
\text { R-squared }\end{array}$ & $\begin{array}{l}30,211 \\
0.131 \\
\end{array}$ & $\begin{array}{l}11,014 \\
0.112 \\
\end{array}$ & $\begin{array}{l}10,443 \\
0.194 \\
\end{array}$ & $\begin{array}{l}8,754 \\
0.160 \\
\end{array}$ \\
\hline
\end{tabular}

Notes: Wealth levels are winsorized at the 99\% level. Robust standard errors in parentheses. For Column 1, standard errors are clustered at the individual level. ${ }^{* * *} p<0.01,{ }^{* *} p<0.05,{ }^{*} p<0.1$ 
Table 11a: Estimated Effects of Cognitive Ability and Financial Literacy on Debt Exposure

\begin{tabular}{lllllllll}
\hline VARIABLES & \multicolumn{7}{c}{ Total Debt } & \multicolumn{7}{c}{ Primary Mortgage } & \multicolumn{1}{l}{ Other Home Loans } & Other Debt \\
\hline Cog Ability & $0.428^{* *}$ & -0.037 & $0.438^{* *}$ & 0.068 & 0.010 & -0.020 & 0.050 & 0.043 \\
& $(0.216)$ & $(0.252)$ & $(0.185)$ & $(0.206)$ & $(0.032)$ & $(0.036)$ & $(0.032)$ & $(0.039)$ \\
Fin Literacy & & $1.071^{* * *}$ & & $0.852^{* * *}$ & & $0.069^{* *}$ & & 0.018 \\
& & $(0.260)$ & & $(0.192)$ & & $(0.033)$ & & $(0.044)$ \\
& & & & & & & & \\
Observations & 2,825 & 2,825 & 2,825 & 2,825 & 2,825 & 2,825 & 2,825 & 2,825 \\
R-squared & 0.075 & 0.082 & 0.061 & 0.023 & 0.024 & 0.035 & 0.048 & 0.035 \\
\hline
\end{tabular}

Notes: Debt levels are winsorized at the $99 \%$ level. For each outcome, the first Column explores the association with cognitive ability and the second Column adds financial literacy to the specification in the first Column. Other explanatory variables include age, gender, marital status, race, education, household income, poor health, working status, and year fixed effects. Standard errors clustered at the individual level in parentheses. ${ }^{* *} p<0.01,{ }^{* *} p<0.05,{ }^{*} p<0.1$.

Table 11b: Marginal Effects of Financial Literacy on Debt Exposure by Age Group

\begin{tabular}{|c|c|c|c|c|}
\hline VARIABLES & Total Debt & Primary Mortgage & Other Home Loans & Other Debt \\
\hline Fin Literacy|age 56-61 & $\begin{array}{c}1.678^{\star * \star} \\
(0.370)\end{array}$ & $\begin{array}{l}1.499^{\star * *} \\
(0.269)\end{array}$ & $\begin{array}{c}0.020 \\
(0.045)\end{array}$ & $\begin{array}{c}0.062 \\
(0.061)\end{array}$ \\
\hline Fin Literacy| age 62-67 & $\begin{array}{c}0.561 \\
(0.366)\end{array}$ & $\begin{array}{c}0.406 \\
(0.266)\end{array}$ & $\begin{array}{l}0.108^{\star *} \\
(0.053)\end{array}$ & $\begin{array}{l}-0.053 \\
(0.057)\end{array}$ \\
\hline Fin Literacy|age 68-73 & $\begin{array}{l}0.683^{*} \\
(0.392)\end{array}$ & $\begin{array}{c}0.273 \\
(0.309)\end{array}$ & $\begin{array}{l}0.106^{*} \\
(0.062)\end{array}$ & $\begin{array}{c}0.049 \\
(0.064)\end{array}$ \\
\hline
\end{tabular}

Notes: Debt levels are winsorized at the $99 \%$ level. Other explanatory variables include age, gender, marital status, race, education, household income, poor health, working status, year fixed effects, and cognitive ability. Standard errors clustered at the individual level in parentheses. ${ }^{* * *} p<0.01,{ }^{* *} p<0.05,{ }^{*}$ $p<0.1$. 
Table 12a: Estimated Effects of Cognitive Ability and Financial Literacy on Wealth and

Financial Fragility

\begin{tabular}{|c|c|c|c|c|c|c|}
\hline VARIABLES & \multicolumn{2}{|c|}{ Net Total Wealth } & \multicolumn{2}{|c|}{ Debt/Assets $>0.5$} & \multicolumn{2}{|c|}{ Liquid Wealth } \\
\hline $\begin{array}{l}\text { Cog Ability } \\
\text { Fin Literacy }\end{array}$ & $\begin{array}{c}5.950^{\star \star \star} \\
(1.583)\end{array}$ & $\begin{array}{c}0.658 \\
(1.647) \\
12.175^{* * *} \\
(1.601)\end{array}$ & $\begin{array}{l}-0.011 \\
(0.010)\end{array}$ & $\begin{array}{c}0.000 \\
(0.011) \\
-0.025^{\star *} \\
(0.011)\end{array}$ & $\begin{array}{l}1.012^{*} \\
(0.525)\end{array}$ & $\begin{array}{c}-0.245 \\
(0.587) \\
2.891^{* * *} \\
(0.553)\end{array}$ \\
\hline $\begin{array}{l}\text { Observations } \\
\text { R-squared }\end{array}$ & $\begin{array}{l}2,825 \\
0.321\end{array}$ & $\begin{array}{l}2,825 \\
0.335\end{array}$ & $\begin{array}{l}2,825 \\
0.039\end{array}$ & $\begin{array}{l}2,825 \\
0.041\end{array}$ & $\begin{array}{l}2,825 \\
0.233\end{array}$ & $\begin{array}{l}2,825 \\
0.239\end{array}$ \\
\hline & \multicolumn{2}{|c|}{ Too Much Debt } & \multicolumn{2}{|c|}{ Biased Perception } & \multicolumn{2}{|c|}{ Debt Repay>5 Years } \\
\hline $\begin{array}{l}\text { Cog Ability } \\
\text { Fin Literacy }\end{array}$ & $\begin{array}{l}-0.020^{*} \\
(0.011)\end{array}$ & $\begin{array}{c}-0.020^{*} \\
(0.011) \\
-0.036^{* * *} \\
(0.011)\end{array}$ & $\begin{array}{l}-0.002 \\
(0.007)\end{array}$ & $\begin{array}{c}0.005 \\
(0.008) \\
-0.015^{*} \\
(0.008)\end{array}$ & $\begin{array}{c}-0.037^{* * *} \\
(0.013)\end{array}$ & $\begin{array}{c}-0.021 \\
(0.015) \\
-0.038^{* *} \\
(0.015)\end{array}$ \\
\hline $\begin{array}{l}\text { Observations } \\
\text { R-squared }\end{array}$ & $\begin{array}{l}2,825 \\
0.086 \\
\end{array}$ & $\begin{array}{l}2,825 \\
0.086\end{array}$ & $\begin{array}{l}2,825 \\
0.017\end{array}$ & $\begin{array}{l}2,825 \\
0.018\end{array}$ & $\begin{array}{l}1,890 \\
0.043\end{array}$ & $\begin{array}{l}1,890 \\
0.047\end{array}$ \\
\hline
\end{tabular}

Notes: Total and liquid wealth levels are winsorized at the $99 \%$ level. For each outcome, the first Column explores the association with cognitive ability and the second Column adds financial literacy to the specification in the first Column. Other explanatory variables include age, gender, marital status, race, education, household income, poor health, working status, and year fixed effects. Standard errors clustered at the individual level in parentheses. ${ }^{* * *} p<0.01,{ }^{* *}$ $p<0.05,{ }^{*} p<0.1$. 
Table 12b: Marginal Effects of Financial Literacy on Wealth and

Financial Fragility by Age Group

\begin{tabular}{|c|c|c|c|}
\hline VARIABLES & Net Total Wealth & Debt/Assets $>0.5$ & Liquid Wealth \\
\hline \multirow{2}{*}{ Fin Literacy|age 56-61 } & $8.904^{* * *}$ & -0.009 & $2.646^{\star \star \star}$ \\
\hline & $(2.247)$ & $(0.014)$ & $(0.800)$ \\
\hline \multirow[t]{2}{*}{ Fin Literacy|age 62-67 } & $13.891^{* * *}$ & $-0.047^{* * *}$ & $1.747^{* *}$ \\
\hline & $(2.140)$ & $(0.015)$ & $(0.784)$ \\
\hline \multirow[t]{2}{*}{ Fin Literacy|age 68-73 } & $16.547^{* * *}$ & -0.025 & $5.516^{* * *}$ \\
\hline & $(3.427)$ & $(0.018)$ & $(1.324)$ \\
\hline \multirow{3}{*}{ Fin Literacy|age 56-61 } & Too Much Debt & Biased Perception & Debt Repay $>5$ Years \\
\hline & $-0.031^{* *}$ & -0.007 & $-0.037^{*}$ \\
\hline & $(0.016)$ & $(0.011)$ & $(0.020)$ \\
\hline \multirow[t]{2}{*}{ Fin Literacy|age 62-67 } & $-0.040^{* * *}$ & $-0.028^{* *}$ & $-0.047^{* *}$ \\
\hline & $(0.015)$ & $(0.012)$ & $(0.022)$ \\
\hline \multirow[t]{2}{*}{ Fin Literacy|age 68-73 } & $-0.038^{*}$ & -0.013 & -0.026 \\
\hline & $(0.020)$ & $(0.013)$ & $(0.028)$ \\
\hline
\end{tabular}

Notes: Total and liquid wealth levels winsorized at the $99 \%$ level. Other explanatory variables include age, gender, marital status, race, education, household income, poor health, working status, year fixed effects, and cognitive ability. Standard errors clustered at the individual level in parentheses. ${ }^{* *} p<0.01,{ }^{* *} p<0.05,{ }^{*} p<0.1$. 